\title{
CARACTERIZAÇÃO DA ATIVIDADE PROTEINÁSICA DIGESTIVA DE Sphenophorus levis (Coleoptera: Curculionidae) E SUA SENSIBILIDADE À CHAGASINA
}

\author{
FRANCISCO CLAUDIO DA CONCEIÇÃO LOPES \\ Engenheiro Agrônomo
}

Orientador: Prof. Dr. MÁRCIO DE C. SILVA FILHO

Dissertação apresentada à Escola Superior de Agricultura "Luíz de Queiróz", Universidade de São Paulo, para obtenção do título de Mestre em Agronomia, Área de Concentração: Genética e Melhoramento de Plantas.

\author{
PIRACICABA \\ Estado de São Paulo - Brasil \\ Junho -2002
}




\section{ERRATA}

Francisco Claudio da Conceição Lopes. Caracterização da atividade proteinásica digestiva de Sphenophorus levis (Coleoptera: Curculionidae) e sua sensibilidade à Chagasina.

\begin{tabular}{|c|c|c|c|c|}
\hline p. & item & linha & onde se lê & leia-se \\
\hline 11. & 3.1 .4 & 27 & Sally & Twining \\
\hline 18 & 3.3 .1 & Legenda & $\begin{array}{l}\text { Figura } 3 \text { - Esquema representativo dos vetores } \\
\text { usados na transformação: Blocos em } \\
\text { negrito com setas em ambas as } \\
\text { figuras: promotor ubi-1: Bloco em verde } \\
\text { na Figura a: gene Cha: Bloco em } \\
\text { branco na Figura b: gene NPTII. }\end{array}$ & $\begin{array}{r}\text { Figura } 3 \text { - Esquema representativo los vetores } \\
\text { usados na transformação: Blocos em } \\
\text { negrito com setas em ambas as } \\
\text { figuras: promotor ubi-1; Bloc em } \\
\text { verde na Figura a. gene Cha : Bloco } \\
\text { em branco na Figura b: gene NPTII } \\
\text { (Adaptado de Christensen e Qauil. } \\
\text { 1996). }\end{array}$ \\
\hline
\end{tabular}

\begin{tabular}{|c|c|c|}
\hline 28 & 41 & sétimo pic \\
\hline 37 & Legenda & 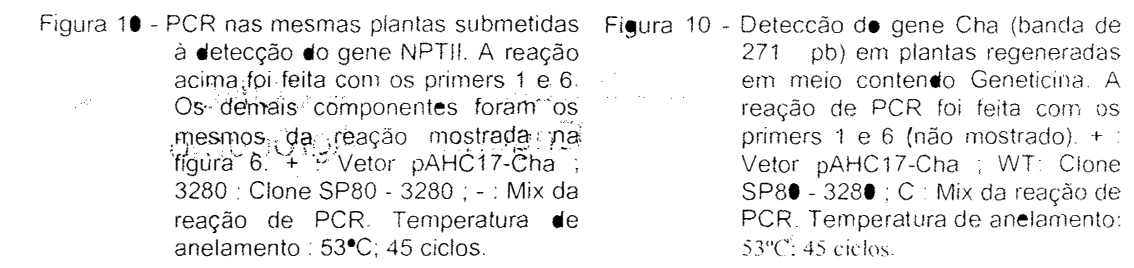 \\
\hline 43 & Legenda & $\begin{array}{l}\text { Tabela 3. Usó de códons em Tripanosoma cruzi e Tabela } 3 \text {. Uso de códons em Tripanosoma } \\
\text { Saccharum officinarum. }\end{array}$ \\
\hline \multirow[t]{2}{*}{$\begin{array}{l}1 . \\
2-\end{array}$} & \multirow{2}{*}{\multicolumn{2}{|c|}{ ERRATA (continuaçāo) }} \\
\hline & & \\
\hline$p$ & item & Informações complementares \\
\hline vis & Lista de Abreviaturas & $\begin{array}{l}\text { 2,4-D = Acio 2,4-Diclorofenoxiacético } \\
\text { BAMCA = Benzoyl-Arginine-7 Amido-4-Methyl-Coumarin } \\
\text { BCIP/NBT = 5-Bromo-4-chloro-3-indolyl-Phosphate/Nitro Blue Tetrazolium } \\
\text { Caps = Acido 3-[Ciclohexamino]-1-Pro ano Sulfônico } \\
\text { DEPC = Diétileno Pirocarbonato } \\
\text { DTT = Ditiotreitol } \\
\text { IPTG = Isopropil-3-D-Tiogalactosideo } \\
\text { MCA = 7-Amido4-Methyl-Coumarin } \\
\text { MS = Meio Murashige e Skoog } \\
\text { NPTII = Neomicina Fosfotransferase } \\
\text { PMSF = Phenylmethylsulphonyl Flu-ride } \\
\text { TE = Tampão Tris-EDTA } \\
\text { X-gal = 5-Bromo-4-Cloto-3-indolil-D-galactopiranisideo }\end{array}$ \\
\hline
\end{tabular}

FERNANDES KVS : SABELUIPA:BARRATT D HP et al The resistance of cowpea seeds to bruchid beetles is not related to levels of cysteine proteinase-inhibitors. Plant Molecular Biology. v.23. n.1, p. $215-219,1993$.

GOODING R.H. Digestive processes of Haematophagous insects. XII. Secretion of trypsin and carboxypeptidase B by Glossina morsitans Westwood (Diptera: Culiciae). Canadian Journal of Zoology. v.55. p.215-222.1969.

Referências Bibliograficas MACEDO ML.R.; FERNANDES K.V.S; SALES M P. et al. Purification and properties of storage proteins (vicilins) from cowpea (vi na-unguiculata) seeds which are susceptible or resistant to the bruchid beetle Callos bruchus maculatus. Brazilian Journal of Medical and Biological Research. v 28 n.2. p.183-190, 1995

SIQUEIRA-JUNIOR C.L.: FERNANDES KV.S.: MACHADO OLT et al. 87 KOa tomato cystatin exhibits properties of a detense protein and forms protein crystals in prosystemin overexpressing transgenic plants. Plant Physiology and Biochemistry $\vee 40,17,3,0.247 .254,2002$ 


\section{Dados Internacionais de Catalogação na Publicação (CIP) DIVISÃO DE BIBLIOTECA E DOCUMENTAÇÃO - ESALQ/USP}

Lopes, Francisco Claudio da Conceição

Caracterização da atividade proteinásica digestiva de Sphenophorus levis (Coleptera : Curculionidae) e sua sensibilidade à chagasina / Francisco Claudio da Conceição Lopes. - - Piracicaba, 2002.

$54 \mathrm{p}$.

Dissertação (mestrado) - - Escola Superior de Agricultura Luiz de Queiroz, 2002. Bibliografia.

1. Ativação enzimática 2. Cana-de-açúcar 3. Enzimas proteoliticas 4. Gorgulhos 5. Insetos nocivos 6. Manejo integrado 7. Resistência genética vegetal I. Titulo

CDD 633.61

"Permitida a cópia total ou parcial deste documento, desde que citada a fonte - $\mathbf{O}$ autor" 
A todos os meus amigos

OFEREÇO

Aos meus pais, Zilda e Manoel; e irmãs,

DEDICO 


\section{AGRADECIMENTOS}

Agradeço a todas as pessoas que, de forma direta ou indireta, contribuíram para a realização deste trabalho, especialmente :

Ao Prof. Dr. Márcio de Castro Silva Filho pela orientação, amizade e incentivo durante a realização deste trabalho.

Com muito carinho agradeço à Dra Maria Cristina Falco pela contribuição no trabalho e amizade.

Ao Prof. Dr. Júlio Scharfstein do Instituto de Biofísica Carlos Chagas Filho/UFRJ por ter colaborado com sugestões e fornecendo a Chagasina recombinante usada nos experimentos.

Ao Prof. Dr. Walter Ribeiro Terra pela valiosa colaboração, permitindo o uso do Laboratório de Bioquímica de Insetos para a realização dos ensaios bioquímicos.

Ao Alcides Batista Júnior pela ajuda na realização dos ensaios bioquímicos.

Aos amigos do Laboratório de Biologia Molecular de Plantas, pela amizade, paciência e incentivo em todos os momentos.

A todos os professores, alunos e funcionários do Departamento de Genética da ESALQ/USP.

Aos funcionários da Biblioteca Central e do Departamento de Genética da ESALQ/USP, pelos auxílios prestados. 


\section{SUMÁRIO}

Página

LISTA DE ABREVIATURAS ........................................................ vii

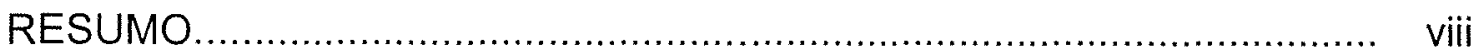

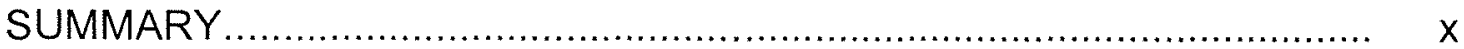

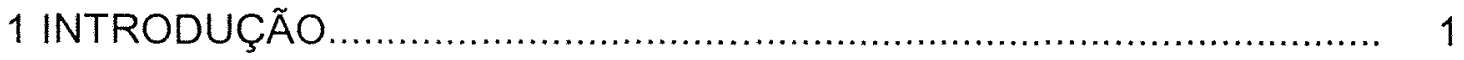

2 REVISÃO DE LITERATURA ....................................................... 3

2.1 Proteinases digestivas dos insetos............................................... 3

2.2 Cisteino proteinases em insetos...................................................... 5

2.3 Controle de insetos através de inibidores de cisteino proteinases...... 7

3 MATERIAL E MÉTODOS.......................................................... 10

3.1 Caracterização das atividades proteinásicas presentes em larvas de Sphenophorus levis (Coleoptera: Curculionidae)................................... 10

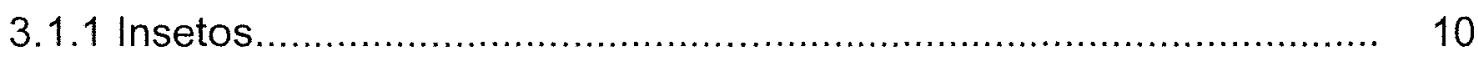

3.1.2 Extração das proteinases........................................................ 10

3.1.3 Cromatografia de troca iônica.................................................... 11

3.1.4 Ensaios de determinação das atividades proteinásicas totais.......... 11

3.1.5 Determinação do $\mathrm{pH}$ ótimo........................................................ 13

3.1.6 Caracterização da atividade de cisteino proteinase em S.levis......... 13

3.2 Ensaios de inibição...................................................................... 14

3.2.1 Efeito dos inibidores E-64 e SBTI ............................................. 14

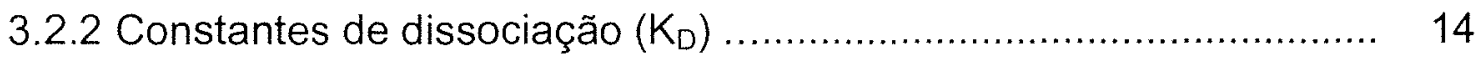

3.3 Transformação de cana-de-açúcar................................................ 15

3.3.1 Construção do vetor................................................................. 15 
3.3.1.2 Clonagem do gene Cha no vetor pAHC17

3.3.1.3 Mini-prep para extração do vetor pAHC17-Cha e sequenciamento do gene.

3.3.2 Obtenção dos calos embriogênicos. 18

3.3.2.1 Assepsia dos palmitos 19

3.3.2.2 Propagação e Manutenção dos Calos. 19

3.3.3 Transformação dos calos via biobalística. 19

3.3.3.1 Preparo das microparticulas. 19

3.3.3.2 Co-precipitação dos plasmídios sobre as micropartículas 20

3.3.3.3 Bombardeamento dos calos 20

3.3.4 Regeneração, seleção e multiplicação dos transformantes. 21

3.4 Análises moleculares. 21

3.4.1 Extração de DNA e PCR. 21

3.4.2 Extração de RNA total e RT-PCR. 22

3.4.3 Extração de proteínas totais e Western Blotting............................... 23

3.5 Ensaios de inibição com extratos de plantas transgências.................. 24

4 RESULTADOS E DISCUSSÃO ...................................................... 25

4.1 Atividades proteinásicas totais em larvas de S. levis........................ 25

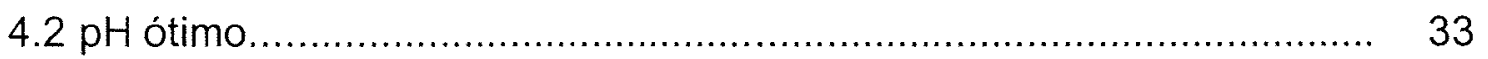

4.3 Atividade de cisteíno proteinases em S. levis.................................. 34

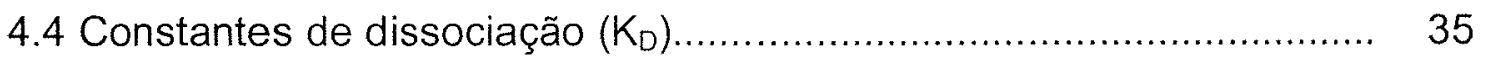

4.5 Caracterização molecular das plantas transgênicas............................ 36

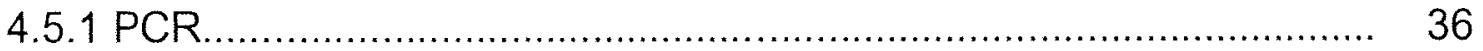

4.5.2 Análise da expressão da Chagasina via RT-PCR _.......................... 37

4.5.3 Análise da expressão da Chagasina via Western Botting................ 38

4.6 Ensaios de inibição com extratos de plantas transgênicas.................. 39

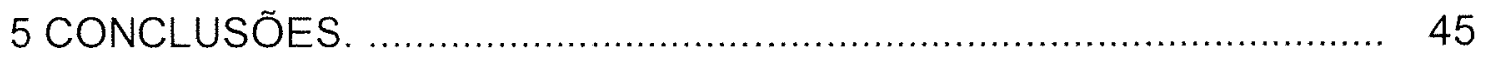

REFERENNCIAS BIBLIOGRÁFICAS .................................................. 46 


\section{LISTA DE ABREVIATURAS}

$\varepsilon-\mathrm{NH}_{2}$-(Cap)-Leu-(S-BzI)CysMCA = $\varepsilon-$ Amino-Caproyl-Leucyl-(S-Benzoyl)-Cys-7Amido-4-Methyl-Coumarin

CasFITC = Caseina-FITC

CBZAMCA = Carbobenzoxy-Arginine-7-Amido-4-Methyl-Coumarin CBZPAMCA = Carbobenzoxy-Phenylalanine-Arginine-7-Amido-4-MethylCoumarin

EDTA = etilenodiamina tetra acetato dissódico

FITC = Fluorescein Isothiocyanate

$\mathrm{IPTG}=$

$\mathrm{kDa}=$ kilo Dalton

$\mathrm{LB}=$ Luria Bertani

PBS = tampão fosfato salino

$P C R=$ reação de polimerase em cadeia

$\mathrm{rpm}=$ rotações por minuto

SAAPMCA=Succinyl-Ala-Ala-Phenylalanine-7-Amido-4-Methyl-Coumarin

SDS = sódio dodecil sulfato

TBS = tampão Tris salino

Tris $=$ Tris(hidroximetil)aminometano

Tween $=$ polioxietilenosorbitol 


\title{
CARACTERIZAÇÃO DA ATIVIDADE PROTEINÁSICA DIGESTIVA DE Sphenophorus levis (Coleoptera: Curculionidae) E SUA SENSIBILIDADE À CHAGASINA
}

\author{
Autor: FRANCISCO CLAUDIO DA CONCEIÇÃO LOPES \\ Orientador: Prof. Dr. MARCIO DE CASTRO SILVA FILHO
}

\section{RESUMO}

Inibidores de proteinase têm sido amplamente utilizados na transformação de plantas visando o controle de insetos-praga. Neste trabalho nós realizamos um detalhado estudo de identificação das atividades proteoliticas presentes no intestino de larvas de Sphenophorus levis (Coleoptera: Curculionidae), uma importante praga da cana-de-açúcar. Foi verificado uma atividade majoritária de cisteíno proteinases (CP's), juntamente com uma atividade menor de serino proteinases. Esses dados nos levaram a transformar cana-de-açúcar com um novo inibidor de cisteíno proteinases denominado Chagasina. Esta proteina foi isolada em Trypanosoma cruzi e sua caracterização bioquímica revelou que ela é um inibidor de cisteíno proteases. Isto foi confirmado através de ensaios enzimáticos com a forma recombinante da proteína que exibiu potente atividade inibitória sobre as CPs presente nos tubos digestivos de $S$. levis. 
Construções gênicas contendo o gene Cha e o gene repórter NPTI/ foram utilizadas para transformação de calos embriogênicos de cana-deaçúcar via biobalística. Plantas selecionadas em meio contendo Geneticina foram submetidas a análises moleculares através de PCR, RT-PCR e Western Blotting que revelaram a integração e expressão do transgene em vários transformantes.

Ensaios com extratos de plantas transgênias foram realizados com o objetivo de avaliar um provável efeito da Chagasina expressa em inibir as CPs de S. levis. Apesar da presença do inibidor nas plantas, não houve inibição da atividade de $\mathrm{CP}$ de $S$. levis, provavelmente em função de sua baixa expressão. 


\title{
CHARACTERIZATION OF THE DIGESTIVE PROTEINASE ACTIVITY OF Sphenophorus levis (Coleoptera : Curculionidae) AND ITS SENSITIVITY TO CHAGASIN
}

\author{
Author: FRANCISCO CLAUDIO DA CONCEIÇÃO LOPES \\ Adviser: Prof. Dr. MARCIO DE CASTRO SILVA FILHO
}

\section{SUMMARY}

Proteinase inhibitors have been broadly employed in plant transformation aiming insect pest control. Here, we report a detailed study of the digestive proteinase activities present in the midgut of Sphenophorus levis (Coleoptera: Curculionidae) larvae, an important pest of sugarcane. It was observed a major activity of cysteine proteinases and a minor level of serine proteinases. These results led us to introduce into the sugarcane genome a new cysteine proteinase inhibitor called Chagasin. This gene was isolated from Trypanosoma cruzi and its biochemical characterization revealed that the gene product is a strong cysteine proteinase inhibitor. Enzymatic assays were performed using the recombinant form of this protein wich displayed potent inhibitory activity against the cysteine proteinases of $S$. levis larvae.

Gene constructs carring the sequence encoding Chagasin and the reporter gene NPTI/ were used to transform embriogenic calli of sugarcane 
via biobalistic. Plants were selected from medium containing Geneticin and were further characterized at the molecular level by PCR, RT-PCR and Western Blotting. Analyses of several transgenic plants confirmed the integration and expression of Chagasin into the sugarcane.

Assays using protein extracts of transgenic plants were performed to address a putative inhibitory effect of Chagasin onto the cysteine proteinases of S. levis. The results showed that here was no inhibitory effect of the sugarcane protein leaf extract on the cysteine proteinase activity of the insect larvae. This observation is probably due to the low expression level observed in the transgenic plants. 


\section{INTRODUÇÃO}

Um dos principais problemas da agricultura são as perdas decorrentes do ataque de insetos. Embora seja difícil quantificar exatamente os prejuizos causados pelas pragas, estima-se que ocorram perdas da ordem de $15 \%$ na produção agricola mundial (Oerke e colaboradores, 1994; Jouanin e colaboradores, 1998).

Com a introdução comercial do DDT (Dicloro-DifenilTricloroetano) na agricultura em 1946 teve início a era dos inseticidas sintéticos que logo se tornaram o principal método de controle de pragas. Mas, ao contrário do que se esperava, o uso intensivo dos inseticidas resultou no desenvolvimento de populações de insetos cada vez mais resistentes. Como conseqüência, os elevados custos sociais, econômicos e ambientais tornaram evidente a necessidade de adoção de métodos alternativos que pudessem minimizar a dependência de tais produtos.

Este pensamento levou ao desenvolvimento de uma nova abordagem para o controle de insetos conhecida como Manejo Integrado de Pragas (MIP). O fundamento básico do MIP consiste no controle da população do inseto mantendo-a abaixo do nível de dano econômico ao invés de tentar erradicá-la. Neste sistema, o uso de variedades geneticamente resistentes ocupa um papel central para o seu sucesso. Além disso, são adotadas diversas práticas de manejo da cultura e do ambiente, que tomadas juntas visam reduzir o uso de inseticidas e de seus efeitos danosos.

Durante décadas a variabilidade genética existente dentro de uma mesma espécie era explorada pelos melhoristas no desenvolvimento de 
novas variedades resistentes. Com os avanços na tecnologia do DNA recombinante tornou-se possivel a utilização de genes de espécies vegetais não relacionadas e até mesmo de espécies fora do reino vegetal como por exemplo bactérias, vírus e animais. A aplicação desta tecnologia em programas de melhoramento juntamente com os conhecimentos nas áreas da biologia molecular e cultura de tecidos vegetais deram origem às plantas transgênicas resistentes. Diversas fontes de resistência têm sido identificadas no controle de insetos, sendo que as mais exploradas até o momento são as toxinas do Bacillus thuringiensis e os inibidores de proteinases.

Anteriormente à transformação das plantas é fundamental que, para cada inseto alvo, um detalhado estudo de identificação de suas proteinases digestivas seja realizado de modo que se possa selecionar entre os genes candidatos aquele ou aqueles potencialmente mais efetivos.

Uma vez realizados tais estudos espera-se que a planta transgênica obtida expresse a proteína de interesse que exercerá seu efeito somente sobre o inseto alvo, conferindo desta forma uma resistência bastante específica.

Neste trabalho foi realizado um estudo de caracterização das atividades proteolíticas digestivas de uma importante praga da cana-de-açúcar, o Sphenophorus levis (Coleoptera: Curculionidae). A partir destes resultados, plantas transgênicas de cana-de-açúcar expressando um novo inibidor de cisteíno proteinases foram obtidas e analisadas quanto ao seu potencial em controlar formas jovens daquele inseto. 


\section{REVISÃO DE LITERATURA}

\subsection{Proteinases digestivas dos insetos}

A classe Insecta inclui mais da metade das espécies existentes em todo mundo. Entre as razões que explicam este sucesso evolutivo está a sua formidável habilidade em explorar os mais diferentes tipos de materiais orgânicos como fonte de alimentos. Esta capacidade digestiva dos insetos depende das enzimas presentes em seu trato digestivo e como elas estão compartimentalizadas (Terra e colaboradores, 1996).

As proteinases, ou endopeptidadases, são de particular interesse em função de envolvimento na digestão de proteínas. Com base em seu mecanismo catalítico elas são divididas em quatro subclasses compreendendo as serino, cisteíno, metalo e aspartil proteinases.

Serino proteinases (SPs) possuem um resíduo de serina e histidina em seu sítio ativo. Elas são semelhantes às tripsinas e quimotripsinas dos vertebrados e possuem $\mathrm{pH}$ ótimo alcalino. Atividade digestiva do tipo tripsina tem sido reportada na maioria das espécies de insetos da ordem Lepidoptera examinadas (Terra e colaboradores, 1996).

Cisteíno proteinases (CPs) possuem um resíduo de cisteína em seu sítio ativo. A maioria dos valores de $\mathrm{pH}$ ótimo até agora registrados são ligeiramente ácidos tendo sido relatado que estas enzimas são bioquimicamente semelhantes às catepsinas $B$ e $L$ de mamiferos (Terra $e$ colaboradores, 1996; Walker e colaboradores, 1998; Wilhite e colaboradores, 2000). 
Aspartil proteinases são proteinas semelhantes às catepsinas D de vertebrados, possuindo $\mathrm{pH}$ ótimo abaixo de 5 devido ao envolvimento de um grupo carboxílico na catálise (Terra e colaboradores, 1996). Existe pouca informação disponivel sobre estas enzimas apesar de sua ocorrência em insetos pertencentes a diversas ordens.

Metalo-proteinases como o próprio nome sugere necessitam de um metal no processo catalítico. Há poucos relatos de ocorrência destas proteinases em insetos. Um caso recente foi documentado por Walker e colaboradores (1998) em tubos digestivos de adultos de Adalia bipuctata L. (Coleoptera: Coccinellidae).

Há na literatura um grande volume de estudos de identificação e caracterização destas proteinases. Na maioria dos casos tem sido observada a ocorrência concomitante de mais de um tipo nos insetos estudados, revelando uma enorme complexidade digestiva (Wolfson \& Murdock, 1990; Terra e Ferreira, 1994; Girard e colaboradores, 1998a).

Apesar disto, serino proteinases são as enzimas predominantes em lepdópteros e dípteros uma vez que estes insetos exibem tubos digestivos alcalinos (Christeller e colaboradores, 1992; Terra \& Ferreira, 1994; Johnston e colaboradores, 1995; Patankar e colaboradores, 2001).

Em coleópteros $\mathrm{o} \mathrm{pH}$ lumenal ao longo dos tubos digestivos varia de ligeiramente ácido a muito alcalino fazendo com que o tipo de proteinase predominante também varie. Observa-se que entre as espécies pertencentes à série Cucujiformia predominam cisteino proteinases (Murdock, 1987; Gillikin e colaboradores, 1992; Michaud e colaboradores, 1995; Terra \& Cristofoletti, 1996), sendo na maioria dos casos, em combinação com aspartil proteinases (Silva \& Xavier-Filho, 1991; Blanco-Labra e colaboradores, 1996; Wilhite e colaboradores, 2000). Outras espécies usam basicamente serino proteinases em sua digestão (Chen e colaboradores, 1992; Bian e colaboradores, 1996; Terra e colaboradores, 1996). 


\subsection{Cisteíno proteinases em insetos}

Cisteíno proteinases são amplamente distribuidas entre os organismos vivos. De acordo com a mais recente classificação elas foram subdivididas em 14 famílias (Rawlings \& Barret, 1994). A maior familia tem a papaína como principal representante incluindo também as catepsinas lisossomais dos mamiferos B e L, entre outras. Todas as CPs do tipo papaína compartilham seqüências primárias e estruturas tridimensionais semelhantes sugerindo uma origem ancestral comum (Turk e colaboradores, 1997).

O primeiro relato da ocorrência de CPs similares às catepsinas dos mamíferos no tubo digestivo dos insetos foi feito por Gooding em 1969. Desde então, diversos trabalhos têm confirmado que estas enzimas são importantes para o processo digestivo dos insetos, principalmente para os coleópteros da série Cucujiformia.

Girard e colaboradores (1998b) identificaram duas atividades principais em larvas de Psylliodes chrysocephala L. (Coleoptera: Curculionidae). Uma em torno do $\mathrm{pH}$ 6-6,5 e outra $40 \%$ menor em torno do $\mathrm{pH}$ 10 , sugerindo a presença de CPS e SPs respectivamente. A análise destas proteinases em gel de atividade revelou quatro bandas ativas em $\mathrm{pH} 6$, que foram totalmente inibidas por E-64 e Orizacistatina I. No entanto, das cincos bandas ativas em pH 10 apenas uma sofreu inibição significativa por PMSF. Apesar deste resultado, os autores suportaram a hipótese de que as demais bandas eram SPs, uma vez que o ensaio foi realizado em pH muito alcalino.

Em outro estudo, Girard e colaboradores (1998c) caracterizaram as proteinases presentes em duas linhagens do curculionídeo Ceutorhynchus assimilis Payk.. Em ambas as linhagens foram observados dois picos, provavelmente resultantes da atividade de CPs, pH 5, e SPs, pH 9. Estes resultados foram confirmados através de ensaios em gel onde as atividades de CPs e SPs foram totalmente inibidas por E-64 e PMSF, respectivamente. 
Um interessante estudo de caracterização das proteinases em larvas e adultos de Adalia bipunctata L. (Coleoptera:Coccinellidae) foi conduzido por (Walker e colaboradores, 1998). Os resultados mostraram a ocorrência exclusiva de CPs nos extratos larvais, com atividade cerca de 5,5 vezes maior do que aquela detectada em adultos. Nestes, além de CPs foi identificada uma banda que teve sua atividade completamente inibida na presença de EDTA através de ensaios em gel, sugerindo a presença de metalo proteinases. Usando substratos especificos para discriminar o tipo de $\mathrm{CP}$, os autores constataram que em larvas ocorria uma catepsina $L$, enquanto em adultos predominou uma catepsina B juntamente com aquela atividade de metalo proteinase.

Bonadé-Bottino e colaboradores (1999) observaram que a principal atividade em larvas de Baris coerulescens (Coleoptera: Curculionidae) era devido a cisteíno proteinases com pH ótimo em torno de 6. Ensaios de atividade em gel evidenciaram quatro bandas que foram totalmente inibidas na presença de Orizacistatina I. Uma atividade cerca de 2,7 vezes menor de serino proteinases, com $\mathrm{pH}$ ótimo em torno de 9 , também foi identificada naqueles insetos.

As Atividades presentes nas larvas do coleóptero Hypera postica Gyllenhal, uma praga da cultura da Alfafa, foram discriminadas como sendo decorrentes de CPs e aspartil proteinases (Wilhite e colaboradores, 2000). A atividade máxima em ensaios de $\mathrm{pH}$ ótimo foi observada em torno de 3,5 com uma atividade remanescente de $50 \%$ em trono do $\mathrm{pH} 5$. A confirmação da presença de CPs e aspartil proteinases foi feita em ensaios com ativadores e inibidores específicos para cada grupo de enzimas. A natureza da atividade das CPs foi analisada através de inibidores específicos para catepsina $B$ e $L$ observando-se que $64 \%$ da atividade em $\mathrm{pH} 5$ era de uma catepsina $\mathrm{L}$. 


\subsection{Controle de insetos através de inibidores de cisteíno proteinases}

Considerando que o sistema digestivo é uma importante interface entre os insetos e o ambiente (Terra \& Ferreira, 1994) diversas estratégias de controle visando atingir suas enzimas digestivas têm sido propostas (Willadsen \& Billingsley, 1996; Pietrantonio \& Gill, 1996, Gatehouse \& Gatehouse, 1998; Hilder \& Bouter, 1999).

No caso particular das pragas agricolas a atenção inicial voltouse para as proteinas do Bacillus thuringiensis (Barton e colaboradores, 1987; Fischhoff e colaboradores, 1987; Vaeck e colaboradores, 1987).

$\mathrm{Na}$ busca por novas fontes de resistência passou-se a explorar os genes que codificam proteínas inibidoras das proteinases digestivas dos insetos. Inibidores de proteinases ocorrem naturalmente numa ampla variedade de organismos estando envolvidos em diversas funções celulares. Nas plantas, estas proteínas são conhecidas há mais de 60 anos, porém, durante muito tempo foram consideradas apenas como compostos do metabolismo secundário com função especifica desconhecida.

A partir da proposição de que eles também fazem parte do sistema de defesa das plantas contra o ataque de insetos (Green \& Ryan, 1972; Shumway e colaboradores, 1976), diversos estudos visando avaliar o seu poder inseticida passaram a ser realizados.

Em 1979, Gatehouse \& Gatehouse demonstraram em experimentos de campo que os elevados niveis de inibidores presentes nas sementes de uma variedade de caupi (Vigna sinensis (L.) Savi) era o fator responsável por sua resistência ao ataque da principal praga da cultura, o Callosobruchus maculatus (F.). Entretanto, resultados posteriores mostraram que na verdade, os efeitos tóxicos não eram causados pelos inibidores de CPS mas por proteínas localizadas na superficie da semente (Fernandes e colaboradores 1993; Macedo e colaboradores, 1995). Mais tarde, variedades comercias de caupi 
expressando esta resistência foram obtidas via melhoramento convencional (Redden e colaboradores, 1983).

Com o auxilio das técnicas de DNA recombinante, genes codificando IP's ativos contra várias espécies de insetos têm sido identificados, isolados e introduzidos em diversa culturas, conferindo resistência a importantes pragas agricolas (Hilder e colaboradores, 1987; Johnson e colaboradores, 1989; McManus e colaboradores, 1994; Leplé e colaboradores, 1995; Xu e colaboradores, 1996; Gatehouse e colaboradores, 1997; Lecardonnel e colaboradores, 1999).

Os Inibidores de cisteíno-proteinases são também conhecidos como cistatinas. Elas são comuns em animais, microrganismos eucarióticos e bactérias, assim como em plantas (Ryan, 1990).

Por causa da importância das cisteíno proteinases no processo digestivo de muitos insetos, genes codificando inibidores de CPs têm sido sugeridos como candidatos para a obtenção de plantas transgênicas resistentes. Em estudos in vitro estes inibidores têm se mostrado potencialmente efetivos no controle principalmente de coleópteros.

A cistatina vegetal melhor caracterizada é a orizacistatina I, isolada a partir de sementes de arroz (Abe e colaboradores, 1992). Desde o isolamento e caracterização do gene Oc-l (Abe e colaboradores, 1987) ele tem sido utilizado, na sua forma natural ou modificada, em eventos de transformação genética.

Plantas transgênicas de tabaco expressando Oc-l foram primeiramente obtidas por Masoud e colaboradores (1993). Posteriormente, Hosoyama e colaboradores (1994), obtiveram plantas transgênicas de arroz expressando Oc-l. Contudo, em nenhum destes estudos foram realizados ensaios para verificar os efeitos do inibidor sobre insetos. Em 1995, Benchekroun e colaboradores, transformaram plantas de batata $e$ demonstraram que extratos protéicos eram ativos sobre as enzimas digestivas de Leptinotarsa decemlineata. 
Experimentos in vivo com Chrisomela tremula alimentadas com álamo expressando Oc-l foram conduzidos por Leplé e colaboradores (1995) que demonstraram aumento na mortalidade dos insetos. Este foi o primeiro estudo mostrando que a expressão de uma cistatina em plantas transgênicas conferia resistência a coleópteros. Mais recentemente, ensaios de inibição in vitro a partir de extratos foliares de plantas transgênicas de tomate superexpressando a pró-sistemina com o extrato intestinal de larvas de Callosobruchus maculatus e Zabrotes subfasciatus mostraram que as atividades proteolíticas das CPs dos insetos foram significativamente inibidas pela presença das cistatinas de tomate (Siqueira-Júnior e colaboradores, 2002).

Em um outro estudo, Lecardonnel e colaboradores (1999) relataram que embora a expressão da orizacistatina I em plantas transgênicas de batata tenha demonstrado um efeito deletério significativo sobre o crescimento e desenvolvimento de larvas de Leptinotarsa decemlineata, esta estratégia deve ser melhorada, o que pode ser alcançado através da utilização de novos inibidores. 


\section{MATERIAL E MÉTODOS}

3.1 Caracterização das atividades proteinásicas presentes em larvas de Sphenophorus levis (Coleoptera: Curculionidae)

\subsubsection{Insetos}

As larvas de Sphenophorus levis (Coleoptera: Curculionidae) foram gentilmente fornecidas pelo Centro de tecnologia Copersucar (CTC). Os insetos foram coletados em áreas infestadas e mantidos em toletes de cana-deaçúcar até o momento da remoção dos tubos digestivos.

\subsubsection{Extração das proteinases}

As larvas foram inicialmente imobilizadas em gelo. Em seguida, seus tubos digestivos foram extraídos em solução salina gelada $(\mathrm{NaCl} 300$ $\mathrm{mM}$ ). As amostras foram homogeneizadas em $1 \mathrm{~mL}$ de água bidestilada em homogeneizador Potter-Elvehjem. O material resultante foi centrifugado a $20.000 \mathrm{~g}$ por 30 minutos à $4^{\circ} \mathrm{C}$. O sobrenadante foi recolhido e estocado a $-20^{\circ} \mathrm{C}$ para posterior utilização como fonte de enzimas. 


\subsubsection{Cromatografia de troca iônica}

Um volume de $280 \mu \mathrm{L}$ do homogeneizado foi aplicado numa coluna aniônica do tipo High $Q$ para a realização da cromatografia em EconoSystem (BioRad, USA). A coluna foi equilibrada em tampão imidazol 20 $\mathrm{mM} \mathrm{pH} \mathrm{7,5} \mathrm{e} \mathrm{as} \mathrm{proteinas} \mathrm{foram} \mathrm{eluídas} \mathrm{no} \mathrm{mesmo} \mathrm{tampão} \mathrm{num} \mathrm{gradiente} \mathrm{de} 0$ a $1 \mathrm{M}$ de $\mathrm{NaCl}$. As frações resultantes (aproximadamente $1 \mathrm{~mL}$ por fração) foram coletadas e ensaiadas com substratos fluorescentes conforme descrito abaixo.

\subsubsection{Ensaios de determinação das atividades proteinásicas totais}

Todos os ensaios enzimáticos aqui descritos foram realizados com substratos fluorimétricos. A temperatura de $30^{\circ} \mathrm{C}$ foi utilizada em todos os experimentos seguindo instruções da União Internacional de Bioquímica e Biologia Molecular. As reações foram interrompidas adicionando-se ácido acético $30 \%$ (para substratos sintéticos) ou ácido tricloroacético (para substratos protéicos). O volume final das reações foi de $1020 \mu \mathrm{L}$. As atividades foram medidas em espectrofotômetro de fluorescência monitorando-se a liberação de MCA através de sua fluorescência ( $\lambda$ excitação $=380 \mathrm{~nm} ; \lambda$ emissão $=460 \mathrm{~nm})$. Em seguida, as emissões foram transformadas para unidades $(U)$ de enzima de modo que tais atividades eram proporcionais à concentração da enzima e ao tempo de ensaio. Uma unidade de enzima (U) é definida como sendo a quantidade que hidrolisa $1 \mu \mathrm{mol}$ de substrato/minuto. As atividades das enzimas eram comparadas com a atividade de ensaios controle.

A determinação dos tipos de atividades presentes em $S$. levis foi realizada utilizando-se substratos protéicos, substratos sintéticos, ativadores e inibidores específicos de enzimas pertencentes a diferentes classes macanísticas.

Os substratos protéicos Caseína e Hemoglobina foram marcados com FITC de acordo com Sally (1984). Os substratos artificiais foram: 
CBZPAMCA, específico para cisteino proteinases do tipo papaina; CBZAMCA, especifico para serino proteinases do tipo tripsina; SAAPMCA, específico para serino proteinases do tipo quimotripsina e $\varepsilon-\mathrm{NH} 2-(\mathrm{Cap})$-Leu-(S-Bzl)CysMCA, um substrato altamente específico para cisteíno proteinases (Alves e colaboradores, 1996). O tampão utilizado nos ensaios foi Citrato-fosfato 100 $\mathrm{mM}$ em dois valores de $\mathrm{pH}: 5,5$ e 3,5.

Os ensaios com substratos artificiais e CasFITC foram realizados em $\mathrm{pH} 5,5$, enquanto os ensaios envolvendo $\mathrm{HbFITC}$ foram feitos em pH 5,5 e 3,5. A razão para usarmos dois substratos protéicos é que CasFITC não é um bom substrato em $\mathrm{pH}$ muito baixo. $\mathrm{O}$ uso de $\mathrm{HbFITC}$ em dois valores de $\mathrm{pH}$ teve por objetivo verificar a presença de proteinases que agem em $\mathrm{pH}$ baixo, como por exemplo, aspartil proteinases. Nos ensaios utilizando $\varepsilon-\mathrm{NH} 2-$ (Cap)-Leu-(S-BzI)CysMCA foram adicionados 1,5 mM de EDTA e DTT ao tampão de ensaio. O EDTA age como inibidor da atividade de metalo proteinases enquanto que o DTT age como ativador de cisteíno proteinases.

Os inibidores utilizados foram: SBTI (Soybean Trypsin Inhibitor, um inibidor natural de serino proteinases do tipo tripsina), E-64 (L-trans-epoxysuccinil-L-leucilamido (4-guanidino) butane, um inibidor sintético de cisteino proteinases), Benzamidina (um inibidor sintético de serino proteinases do tipo tripsina) e Pepstatina (inibidor de aspartil proteinases).

Um detalhe adicional é que todos os experimentos realizados com inibidores e ativadores e com os substratos sintéticos e protéicos foram realizados no mesmo dia em que foi feita a cromatografia. É fato notório que, após a cromatografia, perde-se muita atividade no caso de congelamento das frações. Isto pode gerar resultados cuja interpretação seja equivocada. Portanto, o procedimento adotado garante boa segurança nos resultados apresentados. 


\subsubsection{Determinação do pH ótimo}

$O$ efeito do $\mathrm{pH}$ sobre a atividade das enzimas de $S$. levis foi determinado utilizando-se os substratos sintéticos CBZPAMCA e CBZAAMCA (concentração final $10 \mu \mathrm{M}$ ). A faixa de $\mathrm{pH}$ analisada foi de 3,0 a 11,0 variando de meia em meia unidade. A Tabela 1 contém informações sobre os tampões utilizados.

Tabela 1. Propriedades dos tampões usados para determinação do pH ótimo das enzimas de S. levis.

\begin{tabular}{lcc}
\hline Tampão & Faixa de $\mathrm{pH}$ & Concentração final \\
\hline Citrato Fosfato & 3,0 a 7,0 & $200 \mathrm{mM}$ \\
Fosfato & 7,0 a 8,0 & $200 \mathrm{mM}$ \\
Glicina- $\mathrm{NaOH}$ & 8,0 a 10,0 & $200 \mathrm{mM}$ \\
Caps & 10,0 a 11,0 & $200 \mathrm{mM}$ \\
\hline
\end{tabular}

\subsubsection{Caracterização da atividade de cisteíno proteinase em S. levis}

A contribuição da atividade de cisteíno proteinase para a atividade total foi avaliada em ensaios com os substratos sintéticos CBZPAMCA e CBZAAMCA, ambos na concentração final de $10 \mu \mathrm{M}$. $\mathrm{O}$ tipo de CP presente no homogeneizado de $S$. levis também foi determinado, uma vez que estes substratos são específicos para cisteíno proteinases do tipo catepsina $L$ e $B$,

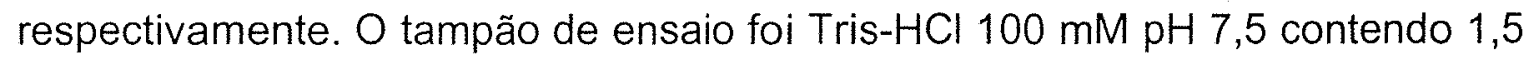
mM de EDTA e 3,0 mM de L-Cisteína, agente redutor utilizado para ativar CPs. Os ensaios foram conduzidos ou na presença de $10 \mu \mathrm{M}$ de $\mathrm{E}-64$ ou $17 \mu \mathrm{M}$ de SBTI. 


\subsection{Ensaios de inibição}

\subsubsection{Efeito dos inibidores E-64 e SBTI}

Ensaios para avaliar a ação dos inibidores E-64 e SBTI foram conduzidos utilizando CBZPAMCA e CBZAAMCA como substratos. O tampão utilizado foi Tris- $\mathrm{HCl} 100 \mathrm{mM} \mathrm{pH} \mathrm{7,5,} \mathrm{contendo} \mathrm{1,5} \mathrm{mM} \mathrm{de} \mathrm{EDTA} \mathrm{e} \mathrm{3,0} \mathrm{mM} \mathrm{de}$ L-cisteína.

\subsubsection{Constantes de dissociação $\left(K_{D}\right)$}

Constantes de dissociação $\left(K_{D}\right)$ foram determinadas para $E-64$ e Chagasina recombinante utilizando-se papaína e homogeneizados de $S$. levis. Os ensaios foram realizados em tampão Tris- $\mathrm{HCl} 100 \mathrm{mM} \mathrm{pH} \mathrm{7,5}$ contendo $17 \mu \mathrm{M}$ de SBTI, 1,5 mM de EDTA e 3,0 mM de L-cisteína.

Quantidades fixas de homogeneizado foram incubadas com diferentes quantidades de inibidores. As atividades resultantes (em mU/tubo) foram plotadas em função das concentrações crescentes do inibidor. A partir do gráfico obtido foram estimadas as concentrações de enzima livre [ $E$ ], do inibidor [ I ] e do complexo enzima-inibidor [ El ]. Os $K_{D} s$ foram calculados através da seguinte equação :

$$
K_{D}=[E][I] /[E I]
$$

Para maiores detalhes ver Knight \& Barret (1976) e Lemos \& Terra (1991). 


\subsection{Transformação de cana-de-açúcar}

\subsubsection{Construção do vetor}

O gene da Chagasina foi introduzido num vetor apropriado para a transformação de cana, o pAHC17 (Christensen \& Quail, 1996), o qual carrega o promotor da ubiquitina do milho, ubi-1 (Figura 1). A seguir são descritos com detalhes todos os passos executados até a obtenção do vetor pronto para a transformação.

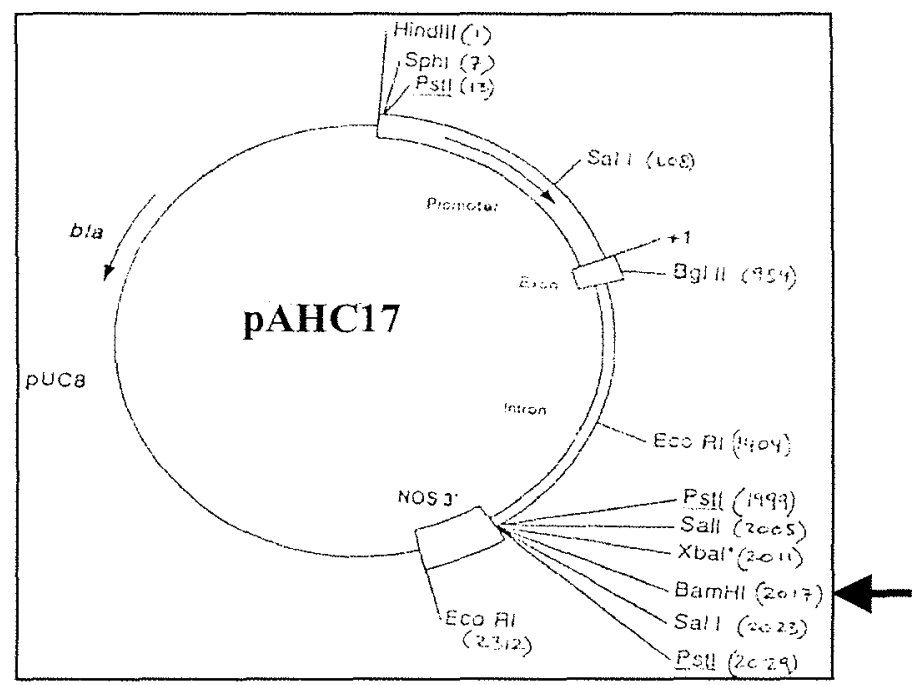

Figura 1 - Plasmídio pAHC17, um vetor de expressão baseado no promotor da ubiquitina do milho ubi-1. O sítio BamHI (seta) é único, portanto, indicado para clonagem de genes com extremidades BamHI. NOS 3': Terminador da Nopalina Sintase.

\subsubsection{Isolamento da sequência natural do gene da Chagasina (Cha-n)}

Todas as reações de digestão, defosforilação, ligação e purificação de fragmentos de DNA descritas abaixo foram realizadas seguindo as instruções contidas no manual do fabricante. 
O gene que codifica a chagasina foi gentilmente cedido pelo Prof. Dr. Júlio Scharfstein (UFRJ). Este gene foi enviado sob duas formas: recombinante $(r)$ (mais adequada à expressão em bactérias) e natural $(n)$ (330 pares de base). Optou-se por utilizar a forma natural por apresentar as sequência completa do cDNA. Baseado em sua sequência, foram construídos primers visando seu isolamento. Nestes primers foram incluídos sítios de restrição para a enzima BamHI (em vermelho), visando posterior inserção no plasmídio pAHC17.

PRIMER 1: 5' CCC G*GA TCC ATG TCC CAC AAG GTG 3'

PRIMER 2 : 5' CCC G*GA TCC TCA GTT TGC CTT GAG 3'

* Sítio de clivagem da enzima BamHI.

Através de PCR com os primers anteriores foi amplificado um fragmento de aproximadamente $350 \mathrm{pb}$ correspondente à Chagasina-n mais a sequência contendo o sítio de BamHI. Após eletroforese em gel de agarose a banda de interesse foi excisada e purificada com o Kit Quiaex II - Quiagen ${ }^{\circledR}$. Por último, o fragmento foi submetido a uma digestão com BamHI.

\subsubsection{Clonagem do gene Cha no vetor $\mathrm{PAHC} 17$}

A preparação do vetor para a inserção do gene Cha consistiu numa digestão com BamHI e posterior defosforilação com a enzima CIAP (Calf Intestinal Alkaline Phosphatase), seguindo o protocolo do fabricante $\left(\right.$ GibcoBRL $^{\circledR}$ ) para ambas as enzimas.

A ligação resultante foi usada para transformar células competentes de $E$. coli, linhagen $D H 5 \alpha$. Para a transformação foram utilizados $200 \mu \mathrm{L}$ de célula e $10 \mu \mathrm{L}$ de cada ligação. Incubou-se por 1 hora no gelo e, em seguida, choque térmico à $42^{\circ} \mathrm{C}$ por 1 minuto, retornado ao gelo novamente. 
Posteriormente, foram adicionados $750 \mu \mathrm{L}$ de meio LB, mantendo as células sob forte agitação $(250 \mathrm{rpm})$ por 1 hora à $37^{\circ} \mathrm{C}$. Centrifugou-se à $13000 \mathrm{rpm}$ por 1 minuto e descartaram-se $700 \mu \mathrm{L}$ do sobrenadante. Após ressuspensão das células (em $500 \mu \mathrm{L}$ de LB), foram inoculados $100 \mu \mathrm{L}$ em placa de Petri contendo meio LB com antibiótico ampicilina (100 mg/L), X-gal (1 $\mathrm{mg} /$ placa) e IPTG $100 \mathrm{mM}$ ( $15 \mu \mathrm{L} /$ placa). Incubou-se à $37^{\circ} \mathrm{C}$ durante a noite.

Como o vetor pAHC17 não possui nenhum gene marcador que permita a seleção das colônias possivelmente transformadas (ver Figura 1), todas as colônias obtidas foram testadas.

\subsubsection{Mini-prep para extração do vetor pAHC17-Cha e sequenciamento do gene}

A extração foi feita seguindo-se o método da lise alcalina (Sambrook e colaboradores., 1989). Amostras do DNA plasmidial foram digeridos com BamHI visando averiguar se o fragmento liberado correspondia ao gene Chag. A sequência do gene Chag confirmada por sequenciamento está representada abaixo, incluindo as sequências introduzidas para clonagem no sítio de restrição BamHI (em azul). A sequência em vermelho corresponde ao sítio de restrição para BamHI (Figura 2).

5'ggg gga tcc atg tcc cac aag gtg acg aaa gcc cat aac ggc gcc aca ttg acg gtg gcc gtc ggc gag ctc gtg gag att cag ctt ccc agc aat ccc acc acc ggg ttc gca tgg tat ttt gaa ggt ggt tgg ttt ctt tca ggg tta ctt tcc atg ttc acc gtc gag aat aag tac ttt cct ccg gac agt aaa cta ttg ggt get ggc ggg acg gag cac ttt cat gtg aca gtg aag gcg gcc ggt acg cac gca gta aat ctc act tac atg cgc ccg tgg aca gga ccc tcg cac gac tcc gag cgt ttc act gta tat ctc aag gca aac tga gga tcc ggg 3'

Figura 2 - Sequência do gene Cha, incluindo os fragmentos contendo os sítios de clivagem da enzima BamHI. 
A construção resultante ( $\mathrm{pAHC} 17-\mathrm{Ch}$ ) juntamente com o vetor pHA9 também utilizado na transformação estão mostradas na Figura 3.

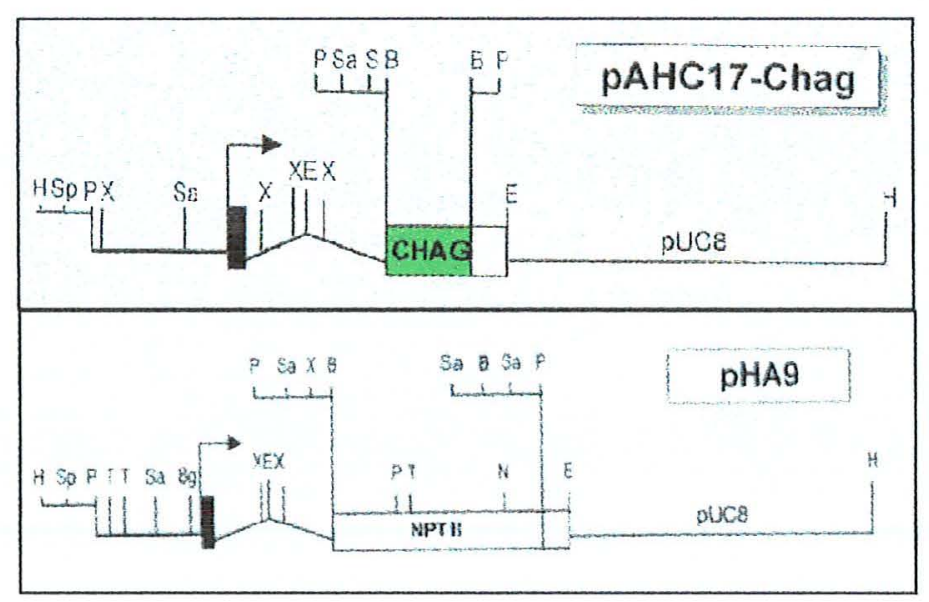

Figura 3 - Esquema representativo dos vetores usados na transformação; Blocos em negrito com setas em ambas as figuras: promotor $u b i-1$; Bloco em verde na Figura : gene Cha; Bloco em branco na Figura : gene NPTII.

\subsubsection{Obtenção dos calos embriogênicos}

Calos embriogênicos de cana-de-açúcar, clone SP80-1842, foram obtidos a partir de explantes de folhas jovens (palmito) fornecidos pelo Centro de Tecnologia Copersucar. O procedimento para obtenção dos calos foi o seguinte :

\subsubsection{Assepsia dos palmitos}

Inicialmente, os palmitos foram mergulhados em etanol absoluto por 1 minuto e a seguir transferidos para uma solução com $30 \%$ de hipoclorito de sódio em água destilada e deixada sob agitação por 15 minutos. Em seguida, foram lavados três vezes com água destilada para remoção do hipoclorito. Posteriormente, foram cortados em seções transversais de 
aproximadamente 3-4 $\mathrm{mm}$, colocados em placas de Petri com meio MS (Murashige e Skoog, 1962), suplementado com $3 \mathrm{mg} / \mathrm{L}$ de 2,4-D, e armazenados em estufa sem iluminação à $27^{\circ} \mathrm{C}$. Constante monitoramento foi realizado eliminando-se materiais contaminados ou oxidados.

\subsubsection{Propagação e Manutenção dos Calos}

Os explantes passaram por repicagens a cada 30 dias. $\mathrm{Na}$ primeira transferência foi realizada uma seleção visual dos calos embriogênicos em formação, conforme descrito por Falco e colaboradores (1996). Estes calos foram repicados a cada 30 dias visando obter-se a maior quantidade possivel de material para transformação. Transcorridos 90 dias os calos estavam aptos para o bombardeamento.

\subsubsection{Transformação dos calos via biobalística}

\subsubsection{Preparo das micropartículas}

Micropartículas (60 mg) de tungstênio M10 foram transferidas para um tubo de microcentrífuga, acrescentando-se $1 \mathrm{~mL}$ de etanol $70 \%$. Misturou-se vigorosamente e manteve-se sob agitação leve durante 15 minutos. Depois centrifugou-se a 15000 g por 5 minutos. O sobrenadante foi descartado e $1 \mathrm{~mL}$ de água destilada estéril foi adicionado ao tubo, misturando-se vigorosamente. Um nova centrifugação foi realizada, repetindo-se a operação de lavagem por mais duas vezes. Após a última lavagem, as partículas foram ressuspensas em $1 \mathrm{~mL}$ de glicerol $50 \%$ estéril. Alíquotas de $50 \mu \mathrm{L}$ foram preparadas e devidamente estocadas. 


\subsubsection{Co-precipitação dos plasmídios sobre as micropartículas}

O DNA contendo o gene de interesse (vetor pAHC17-Chag) foi co-precipitado com o vetor pHA9, que carrega o gene NPTIl da neomicina fosfotransferase (neo), que confere resistência ao antibiótico Geneticina. O procedimento é detalhado a seguir.

Uma alíquota de $50 \mu \mathrm{L}$ da suspensão de micropartículas foi transferida para um tubo de microcentrífuga. Foram adicionados sequencialmente $5 \mu \mathrm{g}$ de cada vetor, $50 \mu \mathrm{L}$ de $\mathrm{CaCl}_{2} 2,5 \mathrm{mM}$ e $20 \mu \mathrm{L}$ de espermidina $0,1 \mathrm{M}$, homogeneizando rápida e delicadamente a suspensão a cada item adicionado. Em seguida, o tubo foi submetido a uma agitação lenta durante 10 minutos à temperatura ambiente. Depois, centrifugou-se e descartou-se o sobrenadante. $150 \mu \mathrm{L}$ de etanol absoluto foram adicionados, centrifugou-se e descartou-se o sobrenadante. Esta última operação foi repetida mais uma vez. Ao final, $24 \mu \mathrm{L}$ de etanol absoluto foram adicionados, homogeneizando vigorosamente a solução. A suspensão foi sonicada por 2 segundos para evitar a formação de aglomerados de micropartículas. Alíquotas de 4,0 $\mu \mathrm{L}$ foram distribuídas no centro de cada membrana carreadora, sendo este o volume de microparticulas usado em cada disparo.

\subsubsection{Bombardeamento dos calos}

Os disparos foram realizados no acelerador de partículas (modelo PDS-1000/He, Bio-Rad) do Laboratório Central do Departamento de Genética - ESALQ/USP. Os parâmetros utilizados foram os seguintes:

Umidade Relativa do ar: entre 30 e $40 \%$.

Distância entre a membrana de ruptura e a membrana carreadora: $2 \mathrm{~cm}$.

Distância entre a membrana carreadora e a tela de retenção: $1,3 \mathrm{~cm}$.

Distância entre a tela de retenção e o alvo: $10 \mathrm{~cm}$.

Pressão de vácuo: 27 polegadas de $\mathrm{Hg}$. 
Pressão de gás hélio: $1100 \mathrm{psi}\left(1 \mathrm{psi}=0,0703 \mathrm{Kgf} / \mathrm{cm}^{2}\right)$.

Os calos foram dispostos na região central da placa $(3 \mathrm{~cm}$ de diâmetro) e bombardeados nas condições descritas acima. Após a realização dos disparos, as placas foram colocadas em estufa sem iluminação à $27^{\circ} \mathrm{C}$ onde permaneceram por 5 dias.

\subsubsection{Regeneração, seleção e multiplicação dos transformantes}

Transcorridos os 5 dias, os calos foram transferidos para placas com meio MS com $35 \mathrm{mg} / \mathrm{L}$ de Geneticina para seleção e regeneração as placas colocadas em sala de luz, com fotoperiodo de 16 horas. Os calos foram mantidos nestas condições até que houvesse regeneração de plantas. Estas, após enraizamento no próprio meio, foram transferidas para recipientes com substrato esterilizado, permanecendo na sala de luz até estarem preparadas para serem transferidas para casa de vegetação.

\subsection{Análises moleculares}

\subsubsection{Extração de DNA e PCR}

DNA genômico de plantas possivelmente transformadas e de plantas controle foi extraído a partir de folhas jovens. As folhas foram maceradas em nitrogênio líquido até o tecido transformar-se em pó. Um volume de aproximadamente $20 \mathrm{~mL}$ deste pó foi transferido para tubo Falcon de $50 \mathrm{~mL}$, adicionando-se $25 \mathrm{~mL}$ de tampão de extração $\mathrm{pH} 7,8-8,0(500 \mathrm{mM}$ de $\mathrm{NaCl}$; $100 \mathrm{mM}$ de Tris- $\mathrm{HCl} \mathrm{pH} 8,0 ; 50 \mathrm{mM}$ de EDTA; $0,84 \%$ de SDS), contendo $0,38 \%$ de bissulfito de sódio. $\mathrm{O}$ tampão foi aquecido à $65^{\circ} \mathrm{C}$ antes de adicioná-lo às amostras. Após homogeneização as amostras foram incubadas à $65^{\circ} \mathrm{C}$ por 30 minutos. Em seguida, adicionou-se clorofórmio:álcool isoamílico (24:1) até completar o volume de $45 \mathrm{~mL}$, mantendo em agitação leve por 10 minutos. 
Centrifugou-se por 15 minutos à $13000 \mathrm{~g}$ para separação das fases. O sobrenadante foi então transferido para tubos novos adicionando-se etanol absoluto (o dobro do volume de sobrenadante) e misturando-se para precipitar os ácidos nucleicos. Antes do resgate do DNA os tubos foram mantidos por 1 hora à $-20^{\circ} \mathrm{C}$. O etanol foi descartado e o DNA foi resgatado com gancho de vidro e transferidos para tubos Eppendorf de $1,5 \mathrm{~mL}$. Posteriormente as amostras foram eluidas em tampão TE em Banho-Maria a $65^{\circ} \mathrm{C}$. O volume de TE variou entre 200 e $1000 \mu \mathrm{L}$ dependendo da quantidade de DNA no tubo. Após resfriamento à temperatura ambiente as amostras foram centrifugadas à $10000 \mathrm{~g}$ por 10 minutos, transferindo-se as suspensões para outros tubos Eppendorf e estocados à $-20^{\circ} \mathrm{C}$.

O DNA obtido foi usado em reações de PCR. Foram desenhados primers que anelam em regiões internas da sequência do gene Chag. Os parâmetros da reação de PCR foram otimizados a partir das condições recomendadas no manual da Taq DNA polimerase recombinante (Life Technologies).

\subsubsection{Extração de RNA total e RT-PCR}

Tecido foliar de plantas jovens em mesmo estádio de desenvolvimento foram macerados em nitrogênio líquido. $\mathrm{Em} 70 \mathrm{mg}$ do macerado acrescentou-se $1 \mathrm{~mL}$ de TRIzol. Em seguida, as amostras foram centrifugadas a $12000 \mathrm{~g}$ por 10 minutos à temperatura de $4^{\circ} \mathrm{C}$. Transferiu-se $\mathrm{o}$ sobrenadante para outros tubos os quais permaneceram em temperatura ambiente por 5 minutos. Adicionou-se $200 \mu \mathrm{L}$ de clorofórmio seguindo-se uma agitação leve por 15 segundos. Novamente, os tubos foram deixados à temperatura ambiente por 3 minutos. A seguir, foram centrifugados a $12000 \mathrm{~g}$ por 15 minutos à $4^{\circ} \mathrm{C}$. A fase aquosa (superior) foi recuperada, pois nela estava contida o RNA, e transferida para outro tubo. Foram adicionados $500 \mu \mathrm{L}$ de isopropanol e a solução foi mantida a temperatura ambiente por 10 minutos. 
Centrifugou-se a solução a $12000 \mathrm{~g}$ por 10 minutos, $4^{\circ} \mathrm{C}$, até a formação de um pellet. O sobrenadante foi descartado permanecendo apenas o pellet o qual foi lavado com $1 \mathrm{~mL}$ de etanol $75 \%$ (preparado com água contendo DEPC). A seguir, centrifugou-se a amostra a $7500 \mathrm{~g}$ por 5 minutos, $4^{\circ} \mathrm{C}$. O sobrenadante foi descartado e o pellet deixado à temperatura ambiente para secar. Por último, o pellet foi eluído em $20 \mu \mathrm{L}$ de água contendo DEPC.

O RNA extraído foi utilizado para síntese de fitas de cDNA através do sistema SuperScript ${ }^{T M}$ - Life Technologies. A reação de RT-PCR foi executada seguindo-se as instruções descritas no manual do fabricante. Como resultado, foram obtidas as fitas de cDNA, utilizadas numa reação de PCR visando amplificação do cDNA de interesse, em nosso caso, o cDNA correspondente à chagasina.

\subsubsection{Extração de proteínas totais e Western Blotting}

Cerca de $500 \mathrm{mg}$ de tecido foliar de plantas jovens em mesmo estádio de desenvolvimento foram macerados em nitrogênio líquido. Adicionouse $5 \mathrm{~mL}$ de tampão de extração (para cada $100 \mathrm{~mL}$ de tampão: $400 \mathrm{mg}$ de $\mathrm{Na}_{2} \mathrm{CO}_{3}, 100 \mathrm{mg}$ de $\mathrm{NaHCO}_{3}, 2 \mathrm{~mL}$ de EDTA 500mM, $50 \mu \mathrm{L}$ de Tween-20, 50 $\mu \mathrm{L}$ de Triton-X e $10 \mathrm{~mL}$ de $\mathrm{NaCl} 5 \mathrm{M}$ ), homogeneizando-se bem as amostras. Em seguida, os tubos foram colocados em gelo por 1 hora e meia, após o que foram centrifugadas por 20 minutos à $14000 \mathrm{rpm}$. Transferiu-se o sobrenadante para tubos novos que foram estocados à $-20^{\circ} \mathrm{C}$. A concentração protéica das amostras foi determinada através do método descrito por Bradford (1976). Para os ensaios de inibição, as concentrações das amostras foram normalizadas para um único valor, adicionando-se tampão de extração.

As amostras foram preparadas misturando-se $45 \mu \mathrm{L}$ do extrato protéico $(50 \mu \mathrm{g}$ de proteina total) a $15 \mu \mathrm{L}$ de tampão de carregamento $(50 \mathrm{mM}$ de Tris-HCl pH 6,8, $100 \mathrm{mM}$ de DTT, $2 \%(\mathrm{w} / \mathrm{v})$ de SDS, $0,1 \%$ de azul de bromofenol e $10 \%(\mathrm{v} / \mathrm{v})$ de glicerol). Em seguida, elas foram fervidas por 5 
minutos e colocadas em gelo até o momento da aplicação em gel desnaturante de poliacrilamida $16 \%$. Após a eletroforese as proteinas foram transferidas para uma membrana de nitrocelulose (GibcoBRL ${ }^{\circledR}$ ). A membrana foi bloqueada em temperatura ambiente por 1 hora com uma solução $5 \%$ de leite desnatado diluído em TBS-Tween20 0,01\%. Após três lavagens consecutivas com TBSTween20 0,01\% (10 minutos cada uma), as membranas foram incubadas durante a noite com o anticorpo primário (rabachagasin) (gentilmente cedido pelo Prof. Julio Scharfstein, UFRJ) diluído 1:500 em TBS-Tween20 0,01\%. Após novas lavagens, a membrana foi incubada com o anticorpo secundário (antrabbit IgG AP conjugate - Promega) por 1 hora diluído 1:10000 em TBSTween20 0,01\%. As bandas imunorreativas foram visualizadas expondo-se a membrana à uma solução de BCIP/NBT (de acordo com instruções do fabricante).

\subsection{Ensaios de inibição com extratos de plantas transgências}

Os extratos foram obtidos como descrito no item $3.4 .3 \mathrm{e}$ utilizados nos ensaios como fonte de inibidor. Inicialmente, uma amostra de Chagasina recombinante $(10 \mu \mathrm{g})$ foi cromatografada em coluna aniônica do tipo High Q. A coluna foi equilibrada em tampão imidazol $20 \mathrm{mM} \mathrm{pH} \mathrm{7,5} \mathrm{e} \mathrm{a} \mathrm{proteína}$ foi eluída no mesmo tampão num gradiente salino de $\mathrm{NaCl}$, variando de 0 a $1 \mathrm{M}$. O mesmo foi feito com amostras de planta não transformada e com as três plantas transgênicas identificadas por Western Blotting. Com o intuito de eliminar as atividades das CPs endógenas da cana-de-açúcar parte das frações obtidas foram fervidas por 3 minutos. Os ensaios foram conduzidos como descrito no item 3.1.4 na presença de 1,5 mM de EDTA, $3 \mathrm{mM}$ de L-cisteina e $17 \mu \mathrm{M}$ de SBTI. 


\section{RESULTADOS E DISCUSSÃO}

\subsection{Atividades proteinásicas totais em larvas de S. levis}

O perfil do ensaio controle sobre CasFITC apresentou dois picos de atividade, 1 e 2, sendo o segundo pico maior que o primeiro (Figura 4). Na presença de SBTI ocorreu uma drástica redução da atividade do pico 2 em cerca de $60 \%$, ao passo que o pico 1 teve sua atividade reduzida em apenas 10\%. Quando Pepstatina foi adicionada juntamente com SBTI, não ocorreram mudanças significativas nos níveis de atividade dos picos 1 e 2 em relação ao ensaio utilizando apenas SBTI. No entanto, na presença de E-64 houve uma notável inibição da atividade em ambos os picos. Ao se adicionar SBTI juntamente com EDTA-DTT, pode-se observar que o pico 1 teve uma atividade semelhante à apresentada quando apenas SBTI foi adicionado ao ensaio. Já o pico 2 apresentou uma atividade cerca de $15 \%$ maior em relação ao ensaio com SBTI. Estes resultados sugerem que serino proteinases do tipo tripsina e cisteino proteinases devem estar presentes em S. levis, uma vez que SBTI e E64 foram capazes de reduzir a proteólise sobre CasFITC. Outra evidência neste sentido é o incremento de atividade no segundo pico decorrente da adição de DTT. 

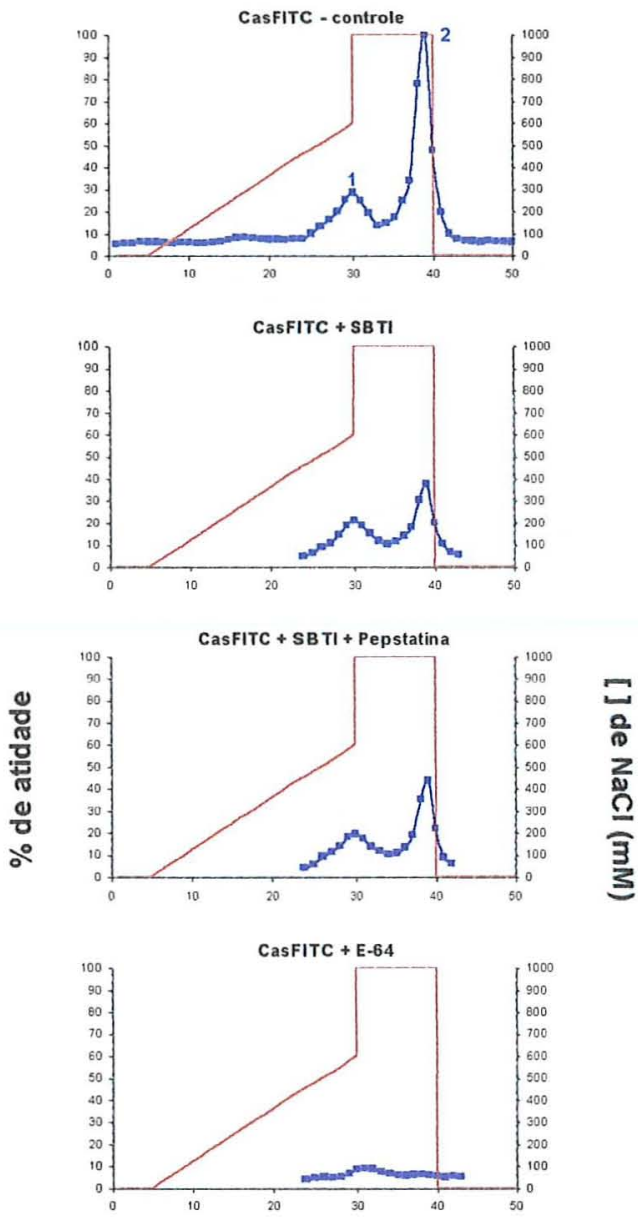

2
$\frac{0}{0}$
2
$\frac{0}{9}$
$\frac{3}{3}$

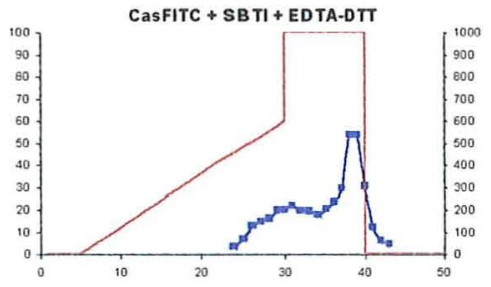

Figura 4 - Atividades sobre CaseínaFITC na presença de ativadores e inibidores de proteinases. Eixo x: fraçổes resultantes da cromatografia. Eixo y: Lado esquerdo - \% das atividades observadas tomando-se o gráfico superior como referência (ensaio controle); Lado direito - concentrações de $\mathrm{NaCl}$, em mM, em que foram eluídas as proteinases ao longo da cromatografia (linha vermelha); pH dos ensaios: 5,5. 
Quando HbFITC foi utilizado como substrato em $\mathrm{pH}$ 5,5, o perfil dos picos de atividade (picos 3 e 4) apresentado foi praticamente o mesmo que se obteve na presença de CasFITC, sugerindo que as mesmas proteinases agiram sobre ambos os substratos protéicos sem que houvesse preferência por algum deles. Entretanto, $\mathrm{HbFITC}$ em pH 3,5 não apresentou picos de atividades relevantes, sugerindo assim a inexistência de aspartil proteinases (Figura 5).

A presença de quimotripsinas foi investigada utilizando-se SAAPMCA. Não houve atividade relevante sobre este substrato, salvo variações da linha de base, o que sugere que a atividade quimotríptica não está presente ou é pouco significativa nos tubos digestivos de S. levis (Figura 5).

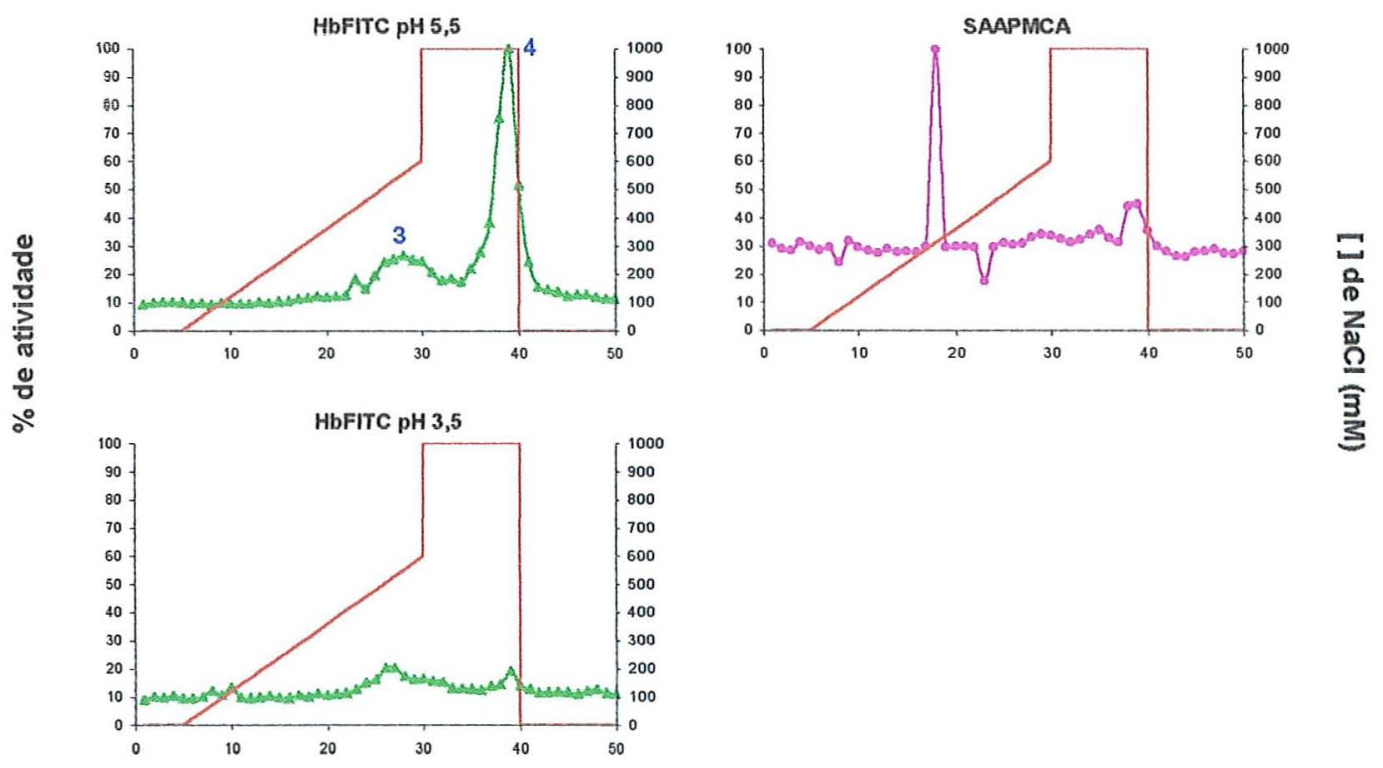

Figura 5 - Atividades de proteinases sobre dois diferentes substratos: HemoglobinaFITC e sobre o substrato sintético SAAPMCA (pH 5,5); Eixo x: frações resultantes da cromatografia. Eixo y: Lado esquerdo - \% das atividades observadas; Lado direito concentrações de $\mathrm{NaCl}$, em mM, em que foram eluídas as proteinases ao longo da cromatografia (linha vermelha). 
Utilizando-se CBZPAMCA como substrato ocorreram três picos distintos (5, 6 e 7), sendo o quinto pico o maior em atividade (Figura 6). $\mathrm{Na}$ presença tanto de SBTI quanto de Benzamidina nota-se que o pico 5 teve sua atividade completamente abolida, permanecendo os picos 6 e 7 praticamente inalterados em relação ao ensaio controle. Quando E-64 foi adicionado ao ensaio, o efeito observado foi justamente o oposto: o pico 5 permaneceu com sua atividade nos mesmos patamares em relação ao controle, ao passo que os picos 6 e 7 tiveram suas respectivas atividades completamente inibidas. Essas observações permitem inferir que a atividade mostrada no pico 5 é, provavelmente, decorrente da ação exclusiva de tripsinas e que as atividades dos picos 6 e 7 são referentes principalmente a cisteíno proteinases Isto, no entanto, não exclui a possibilidade de haver tripsinas agindo conjuntamnete com CPs nas frações correspondentes aos picos 6 e 7 , pois CBZPAMCA também pode ser clivado por estas proteinases.

Nos ensaios em que se utilizou $\varepsilon-\mathrm{NH}_{2}$-(Cap)-Leu-(SBzl)CysMCA (Figura 7) foram observados pelo menos três picos de atividade (picos 8,9 e 10), sendo que o pico 10 coincidiu exatamente com os picos 2 e 7 (Figuras 4 e 6 , respectivamente). Na presença de E-64 houve completa inibição de todas aquelas atividades, semelhante ao que aconteceu nos ensaios com CasFITC e CBZPAMCA. Uma vez que o substrato utilizado é altamente específico para CPS e considerando ainda a inibição causada pelo E-64, sugere-se a presença de CPs em S. levis. Este não é um fato surpreendente, visto que esse besouro pertence à família Curculionidae, que está inclusa na série Cucujiformia, é reconhecido por apresentar este tipo de proteinases (Terra \& Cristofoletti, 1996). 

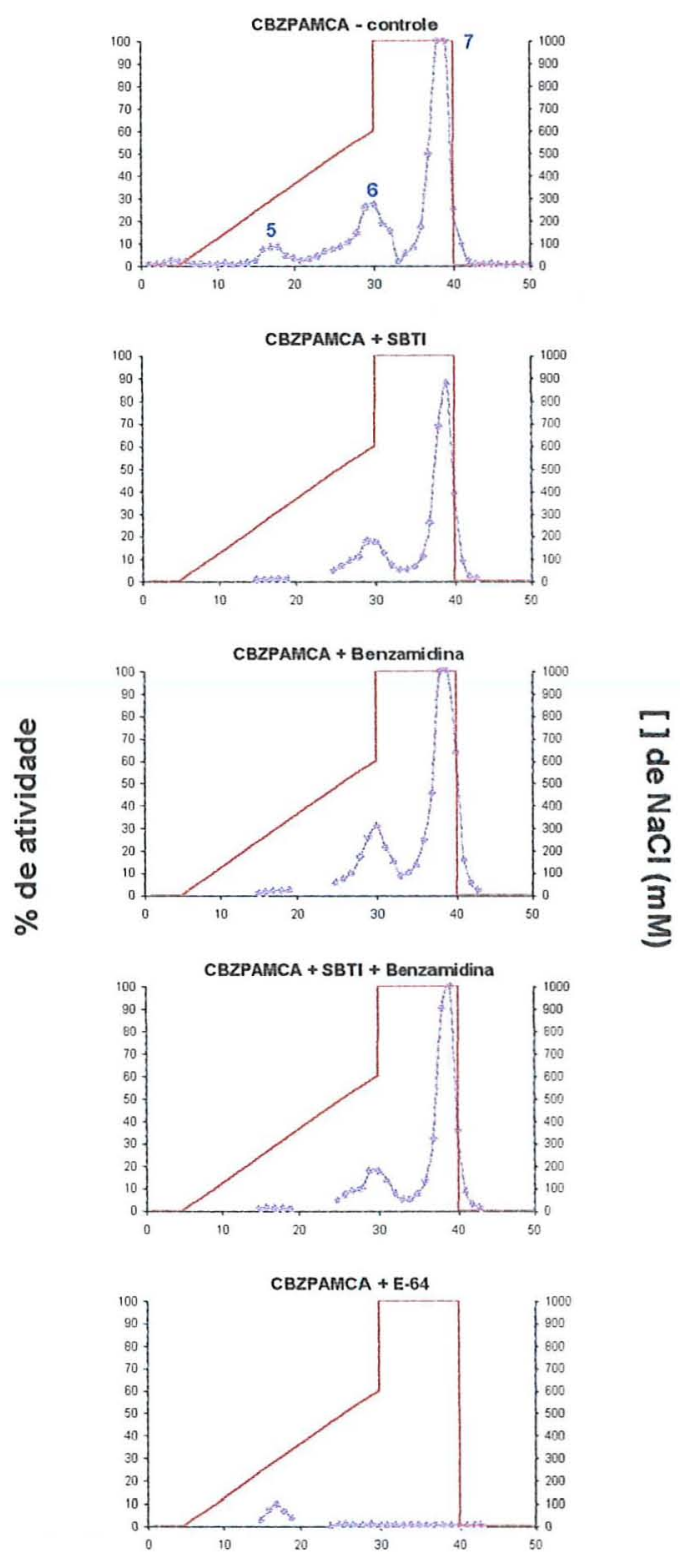

Figura 6 - Atividades sobre o substrato sintético CBZPAMCA na presença dos inibidores SBTI, Benzamidina e E-64. Eixo x: frações resultantes da cromatografia. Eixo y: Lado esquerdo - \% das atividades observadas tomando-se o gráfico superior como referência (ensaio controle); Lado direito - concentrações de $\mathrm{NaCl}$, em $\mathrm{mM}$, em que foram eluídas as proteinases ao longo da cromatografia (linha vermelha); $\mathrm{pH}$ dos ensaios: 5,5 . 

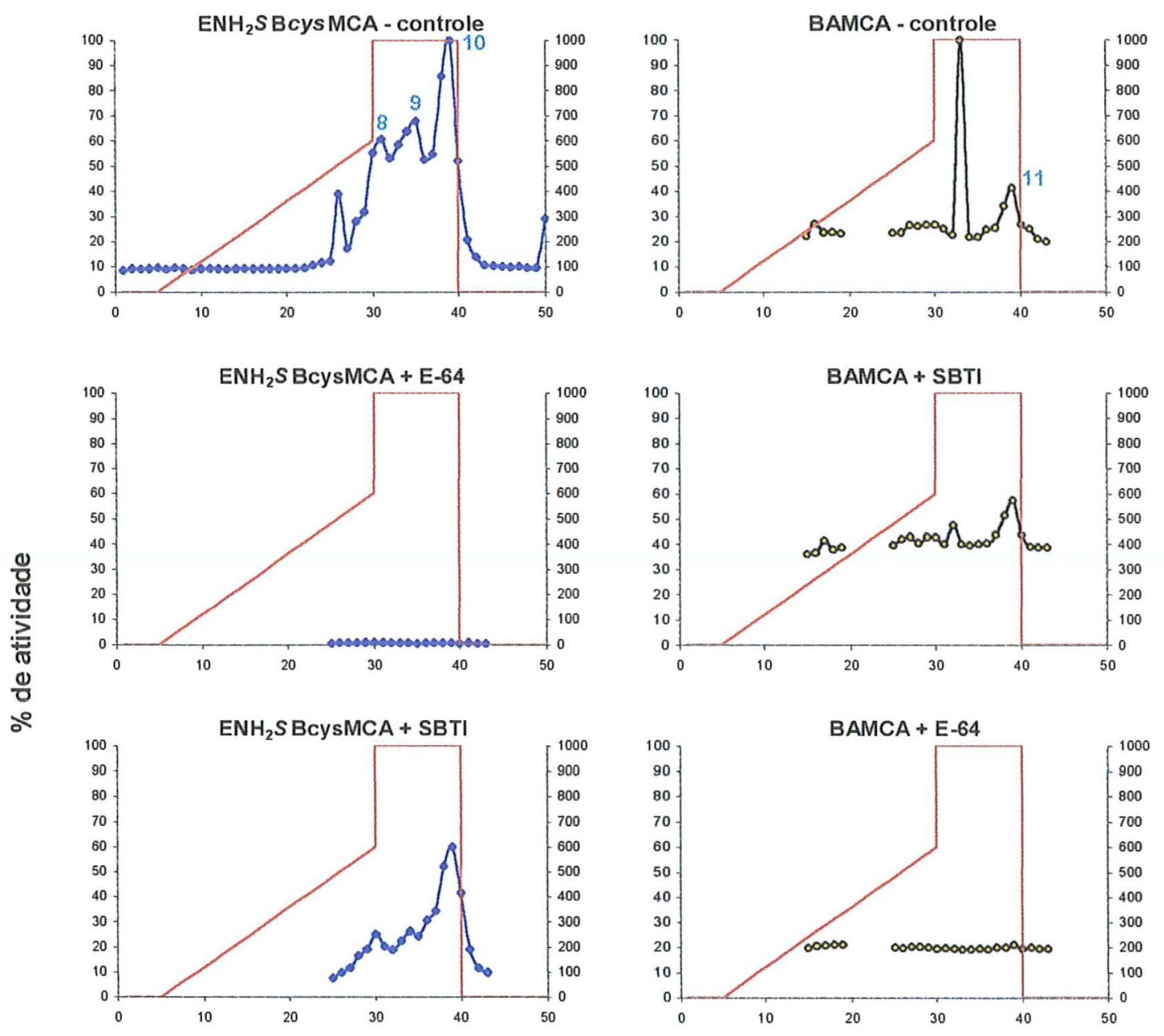

Figura 7 - Atividades sobre os substratos sintéticos $\varepsilon \mathrm{NH}_{2} \mathrm{SBcysMCA}$ e BAMCA na presença dos inibidores SBTI e E-64. Eixo x: frações resultantes da cromatografia. Eixo y: Lado esquerdo - \% das atividades observadas tomando-se os gráficos superiores de cada ensaio como referência (ensaios controle); Lado direito - concentrações de $\mathrm{NaCl}$, em $\mathrm{mM}$, em que foram eluídas as proteinases ao longo da cromatografia (linha vermelha); $\mathrm{pH}$ dos ensaios: 5,5.

Curiosamente, a adição de SBTI resultou num decréscimo nas atividades dos três picos, em torno de $35 \%$ a $45 \%$, em relação ao controle. Este resultado sugere que tripsinas também seriam capazes de clivar $\varepsilon-\mathrm{NH}_{2}-(\mathrm{Cap})$ Leu-(S-Bzl)CysMCA. No entanto, segundo Alves e colaboradores (1996), este 
substrato é totalmente resistente à hidrólise por SPs (tanto tripsinas como quimotripsinas) o que nos leva a supor a existência de CPs sensiveis à ação do SBTI, o que é algo inusitado, posto que não há na literatura relato de CPS sensiveis a inibidores de serino proteinases.

Para confirmarmos ou não a presença de tripsinas agindo no ensaio anterior utilizamos o substrato CBZAMCA, um substrato normalmente usado para diagnosticar a presença de tripsinas. $O$ ensaio revelou a presença de um tênue pico (11) de atividade entre as frações 35 e 41 que é coincidente com o pico 10, porém, de menor atividade (Figura 7). Isto sugere a presença de tripsinas nestas frações. Porém, na presença de SBTI esse pico manteve sua atividade semelhante à apresentada no controle, e desapareceu quando E-64 foi adicionado ao ensaio. A partir destes resultados duas hipóteses podem ser levantadas: a primeira de que esta atividade é decorrente de tripsinas pouco sensiveis à ação do SBTI e ao mesmo tempo muito sensiveis a E-64; e a segunda de que tal atividade é decorrente de CPs agindo sobre CBZAMCA.

A primeira hipótese nos parece bastante razoável pois insetos da série Cucujiformia são descendentes de coleópteros que se adaptaram a ingerir alimentos naturalmente ricos em inibidores de serino proteinases (Terra \& Cristofoletti, 1996). Desta forma, o constante contato com tais inibidores poderia ter levado à expressão constitutiva de tripsinas resistentes aos seus inibidores característicos.

Considerando a segunda hipótese, há na literatura diversos relatos da ocorrência de cisteíno proteinases que apresentam forte atividade proteolítica dirigida contra ligações contendo um resíduo de arginina, um mecanismo catalítico típico de tripsinas (Barret e colaboradores,1982; Uhlmann e colaboradores, 2000; Banbulla e colaboradores, 2001). Estas CPs foram recentemente reunidas no clã $C D$ que inclui diversas enzimas encontradas em eucariotos e procariotos. A mais conhecida é a família $\mathrm{C} 11$ à qual pertence a Clostripaina, da bactéria Clostridium histolyticum, incluindo também as famílias C13, C14, C25 e C50 (Rawlings \& Barrett, 1994; Barrett \& Rawlings, 2001). 
Baseando-se nos resultados apresentados nas Figuras 4, 6 e 7, observa-se que os picos 1, 6 e 8 e 2, 7 e 10 correspondem às mesmas frações em seus respectivos ensaios. Em todos os ensaios em que foi utilizado somente SBTI houve algum nivel de inibição, com exceção do ensaio com CBZAMCA, pico 11. Assim, não é possível definir se as enzimas responsáveis pelas atividades são serino proteinases cuja susceptibilidade ao E-64 é muito maior do que ao SBTI e Benzamidina, ou se são cisteíno proteinases.

Entretanto, ao se comparar os gráficos onde são mostrados os perfis de atividade sobre $\varepsilon-\mathrm{NH}_{2}$-(Cap)-Leu-(S-BzI)CysMCA e sobre CasFITC na presença de SBTI e EDTA-DTT (Figuras 4 e 7, respectivamente), pode-se notar que, em relação aos seus respectivos controles, os perfis de atividade são praticamente iguais. Conforme mencionado anteriormente, é pouco provável que serino proteinases possuam a capacidade de hidrolisar $\varepsilon-\mathrm{NH}_{2}$-(Cap)-Leu(S-BzI)CysMCA . EDTA-DTT foi utilizado nos ensaios como ativador de CPs. Nos dois ensaios, as máximas atividades verificadas foram semelhantes àquelas obtidas no ensaio com CasFITC e SBTI, sem EDTA-DTT. Dessa forma, a conclusão a que se chega é a de que a principal atividade proteinásica verificada nos ensaios é decorrente de cisteíno proteinases as quais se mostraram parcialmente sensiveis à ação do SBTI, aspecto bastante interessante.

Há também a ocorrência de tripsina em $S$. levis, só que em menor quantidade do que cisteíno proteinases, visto que o pico 5 evidenciado no ensaio com CBZPAMCA (Figura 6), fortemente afetado por SBTI e Benzamidina e insensivel a E-64, não possui correspondente no ensaio controle sobre CasFITC (Figura 4). 


\section{$4.2 \mathrm{pH}$ ótimo}

Os ensaios de $\mathrm{pH}$ ótimo evidenciaram perfis de atividade muito semelhantes para ambos os substratos utilizados, com máximas atividades em torno dos pHs 7,5 e 10 (Figura 8). Para nos certificarmos da natureza exata destas atividades, os ensaios foram realizados também na presença de EDTA, L-cisteína e SBTI.

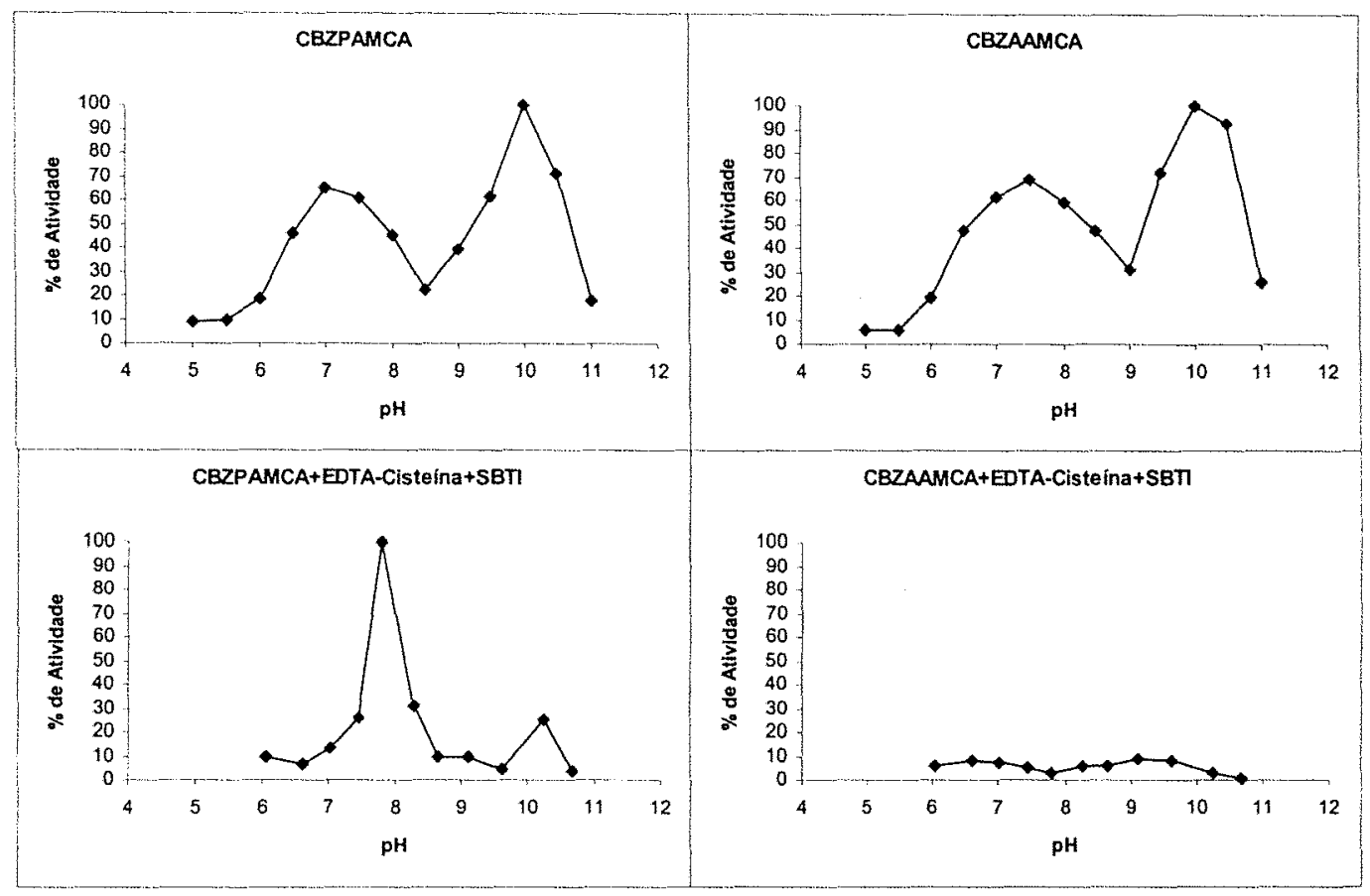

Figura 8 - Efeito do $\mathrm{pH}$ sobre as atividades proteinásicas de $S$. levis. Os ensaios foram realizados sem e com EDTA, L-cisteina e SBTI adicionados ao tampão de ensaio.

No ensaio com CBZPAMCA a atividade em torno do $\mathrm{pH} 10$ sofreu uma drástica redução, sugerindo que tripsinas são as responsáveis por tal atividade. Isto é consistente com os valores de $\mathrm{pH}$ ótimo normalmente relatados na literatura para estas enzimas. Considerando que o substrato usado é bem mais especifico para CPs e o fato da atividade em torno do $\mathrm{pH} 7,5$ ter se 
é bem mais específico para CPs e o fato da atividade em torno do $\mathrm{pH} 7,5$ ter se mantido na presença de L-cisteína, é muito provável que esta atividade seja principalmente de CPs, embora estas enzimas possuam pHs ótimos ligeiramente ácidos.

Ambos os picos tiveram suas atividades totalmente inibidas no ensaio com CBZAAMCA. indicando que basicamente havia tripsinas agindo sobre este substrato.

Diversos estudos têm mostrado que CPs semelhantes às catepsinas $L$ apresentam grande afinidade pelo substrato CBZPAMCA. Nos ensaios anteriores a atividade mais expressiva foi observada no ensaio com este substrato e na presença de ativadores de CPs, o que nos leva a crer que a principal CP S. levis é uma catepsina L.

\subsection{Atividade de cisteíno proteinases em S. levis}

Os ensaios utilizando os inibidores E-64 e SBTI foram realizados com o propósito de avaliar a contribuição de CPs e SPs para a digestão em $S$. levis em pH 7,5.

Os resultados foram muito semelhantes para ambos os substratos utilizados (Tabela 2). Praticamente toda a atividade observada foi anulada na presença dos dois inibidores. Analisando o efeito de cada inibidor individualmente, verifica-se que, utilizando CBZPAMCA como substrato, E-64 reduziu a atividade em $80 \%$ quando comparada ao controle, enquanto SBTI provocou uma redução em torno de $37 \%$. No ensaio com CBZAAMCA, as inibições obtidas foram da ordem de $73 \%$ e $27 \%$ para E-64 e SBTI, respectivamente. 
Tabela 2. Atividade inibitória sobre homogeneizado de S. levis.

\begin{tabular}{cccc}
\hline & \multicolumn{3}{c}{ Atividade remanescente (\%) } \\
\cline { 2 - 4 } Substrato & E-64 & SBTI & E-64 + SBTI \\
\hline CBZPAMCA & 19,6 & 63,1 & 0,8 \\
CBZAAMCA & 27,4 & 72,7 & 1,2 \\
\hline
\end{tabular}

Os resultados anteriores sugerindo que SBTI pode estar agindo sobre algumas CPs de $S$. levis, poderiam explicar o alto nível de inibição obtido em sua presença no ensaio com CBZPAMCA, principalmente.

\subsection{Constantes de dissociação $\left(K_{D}\right)$}

Diversos inibidores têm sido isolados e estudos têm mostrado seu potencial em conferir proteção contra insetos pertencentes a diferentes ordens. A escolha de um ou mais destes inibidores é uma etapa critica na obtenção de uma planta transgênica resistente. Christeller \& Shaw (1989), citados por Hilder \& Bouter (1999), propuseram que a constante de dissociação $\left(K_{D}\right)$ pode ser utilizada para selecionar o inibidor mais efetivo para uma situação particular.

Assim, constantes de dissociação foram obtidas para as CPs de S. levis, através de titulação do homogeneizado com os inibidores E-64 e Chagasina. A partir dos gráficos apresentados na Figura 9 , os valores de $K_{D}$ foram calculados conforme descrito em Materias e Métodos. 


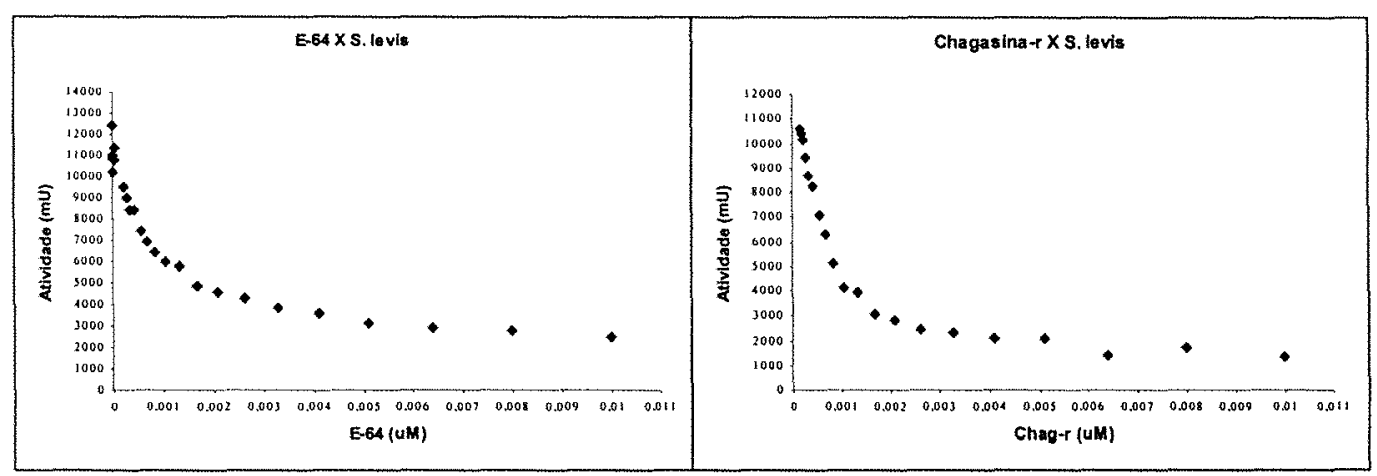

Figura 9 - Inibição da atividade de CPs presentes no homogeneizado de S. levis pelos inibidores E-64 e Chagasina. O substrato utilizado foi CBZPAMCA em tampão Tris- $\mathrm{HCl} 100 \mathrm{mM} \mathrm{pH} \mathrm{7,5,} \mathrm{contendo} 17 \mu \mathrm{M}$ de SBTI.

$O K_{D}$ de $E-64$ foi de 560 pM enquanto que para Chagasina foi de $160 \mathrm{pM}$. Chagasina mostrou ser um inibidor tão efetivo quanto E-64, um inibidor padrão amplamente utilizado para diagnosticar a presença de CPs. Estes resultados sugerem que a expressão da Chagasina em plantas poderia conferir resistência a insetos que se baseiam em CPs para realizar sua digestão, como por exemplo, coleópteros.

\subsection{Caracterização molecular das plantas transgênicas}

\subsubsection{PCR}

Análises moleculares baseadas em PCR foram realizadas com o DNA extraído de folhas jovens das plantas selecionadas no processo de transformação, visando identificar aquelas que receberam o transgene (Figura 10). 


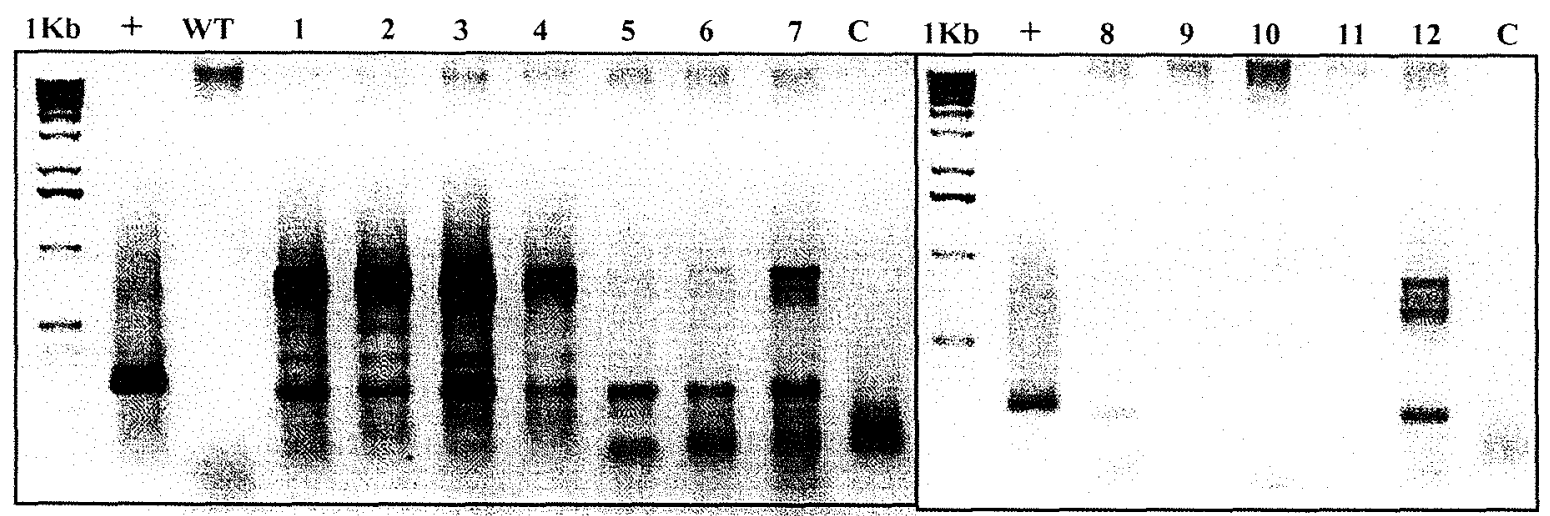

Figura 10 - PCR nas mesmas plantas submetidas à detecção do gene NPTII. A reação acima foi feita com os primers 1 e 6 . Os demais componentes foram os mesmos da reação mostrada na figura $6 .+$ : Vetor pAHC17-Cha ; 3280 : Clone SP80 - 3280 ; - : Mix da reação de PCR. Temperatura de anelamento : $53^{\circ} \mathrm{C} ; 45$ ciclos.

Observa-se a integração do gene da chagasina em todas as plantas analisadas. Além destas, outras plantas PCR positivas foram identificadas (não mostrado).

\subsubsection{Análise da expressão da Chagasina via RT-PCR}

Ao total foram analisadas 18 plantas por RT-PCR, das quais 14 apresentaram algum nivel de expressão. Na Figura 11 bandas correspondentes à chagasina podem ser observadas em todas as plantas. Isto indica que está havendo expressão do gene, apesar de também serem identificados fragmentos inesperados, provavelmente resultado de amplificações não específicas. No entanto, podem ser observadas diferenças nos niveis de expressão o que poderia ser explicado ou por um efeito de posição ou por diferenças no número de cópias inseridas no genoma. 


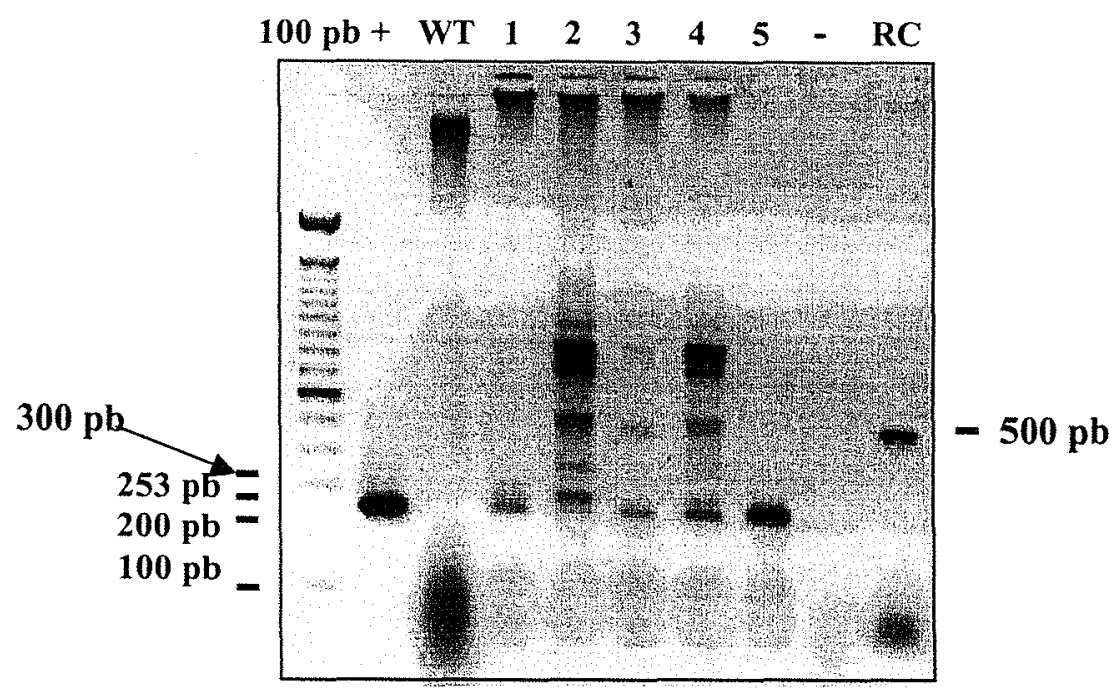

Figura 11 - Expressão da chagasina em plantas de cana-de-açúcar. WT: planta não transformada (SP80-3280); RC controle da reação de RT-PCR (Fragmento de $500 \mathrm{pb}$ ); +: plasmídio com o gene da chagasina; - : Mix da reação. O fragmento amplificado possui $253 \mathrm{pb}$.

\subsubsection{Análise da expressão da Chagasina via Western Blotting}

A presença da proteína foi analisada através de Western Blotting a partir de extratos protéicos totais obtidos de folhas jovens. Foram analisadas apenas três plantas cuja expressão do RNA foi confirmada por RTPCR.

Em todas as plantas apareceram bandas correspondentes ao tamanho esperado da proteína $\left(M_{r}\right.$ 12.031) (Monteiro e colaboradores, 2001). Embora no ensaio não tenha sido utilizada a forma recombinante da proteína $\left(M_{r}\right.$ 13.854) como controle positivo, o fato de não ter havido marcação alguma na planta não transformada é um bom indicativo de que aquelas bandas nas plantas transformadas correspondam à Chagasina (Figura 12). 


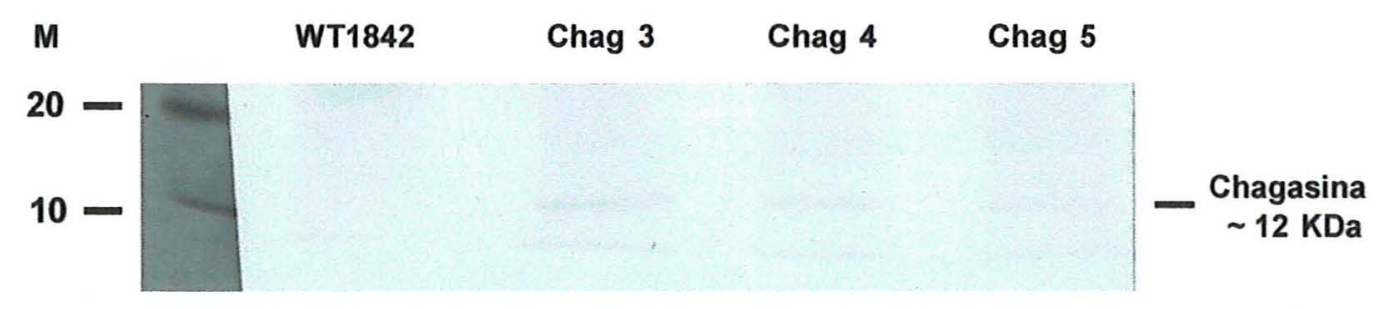

Figura 12 - Ensaio de imunodetecção da chagasina em plantas de cana-deaçúcar. WT: planta não transformada; Chag 3, 4 e 5: plantas transformadas; M: Marcador de peso molecular (10 Kda Protein Ladder, GibcoBRL) corado com Comassie Blue. As bandas logo abaixo daquelas correspondentes à Chagasina representam a frente de corrida das amostras no gel.

\subsection{Ensaios de inibição com extratos de plantas transgênicas}

Os experimentos realizados mostraram que quando a Chagasina recombinante pura foi cromatografada, esta distribuiu-se em duas populações distintas: uma que não interagiu com a coluna e outra que elui no gradiente de $\mathrm{NaCl}$. Nas frações onde se encontra o inibidor, a atividade de $\mathrm{CP}$ de $S$. levis foi completamente anulada (Figura 13).

Extratos de plantas não transformada e plantas transgênicas foram cromatografados. Nas frações da planta não transformada foram detectadas pelo menos duas populações distintas de CPs, as quais tiveram suas atividades completamente inativadas fervendo-se as fraçöes por 3 minutos (Figura 14). Estas mesmas atividades endógenas de CPs foram discriminadas nas plantas transgênicas sendo também inativadas através de fervura (não mostrado). Este procedimento foi um artifício necessário para eliminarmos as atividades endógenas da cana evitando assim que elas se confundissem com as atividades de CPs de S. levis. 


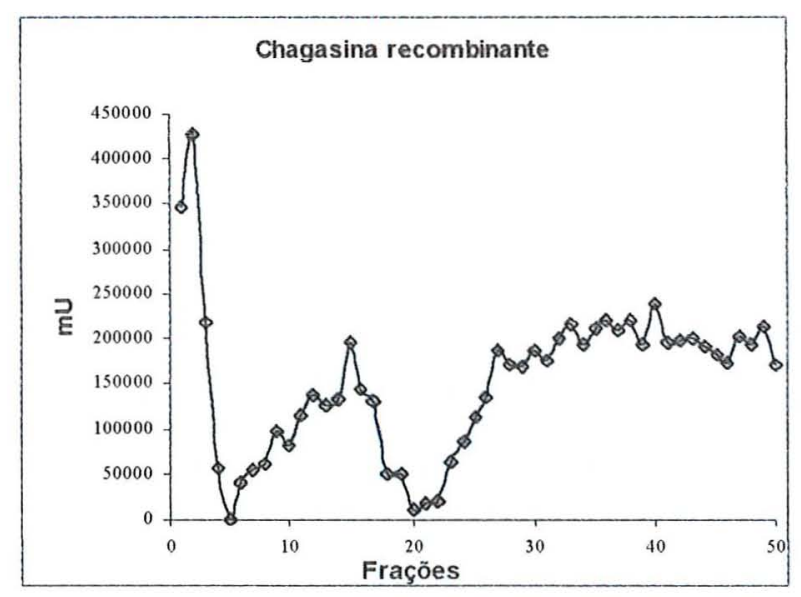

Figura 13 - Perfil de inibição contra homogeneizado de S. levis obtido com a cromatografia da Chagasina recombinante pura. Um total de $10 \mu \mathrm{g}$ de proteína foi aplicado na coluna. O substrato utilizado foi CBZPAMCA.

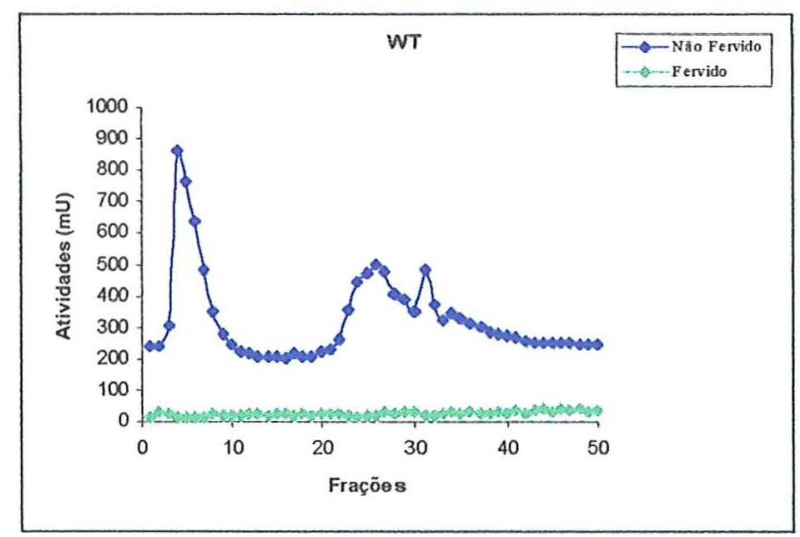

Figura 14 - Perfis de atividades sobre o substrato CBZPAMCA obtidos com a cromatografia do extrato protéico da planta não transformada.

Num outro ensaio com as frações fervidas da planta não transformadas foram adicionadas a cada fração a mesma quantidade de homogeneizado de S. levis. Os resultados revelaram a ocorrência de duas atividade de inibição resultante de inibidores endógenos da cana que não foram inativados pelo tempo de fervura adotado (Figura 15). A principal atividade 
localizou-se entre as frações 1 e 10, praticamente coincidente com uma das regiões de inibição obtidas no ensaio com as frações da Chagasina recombinante.

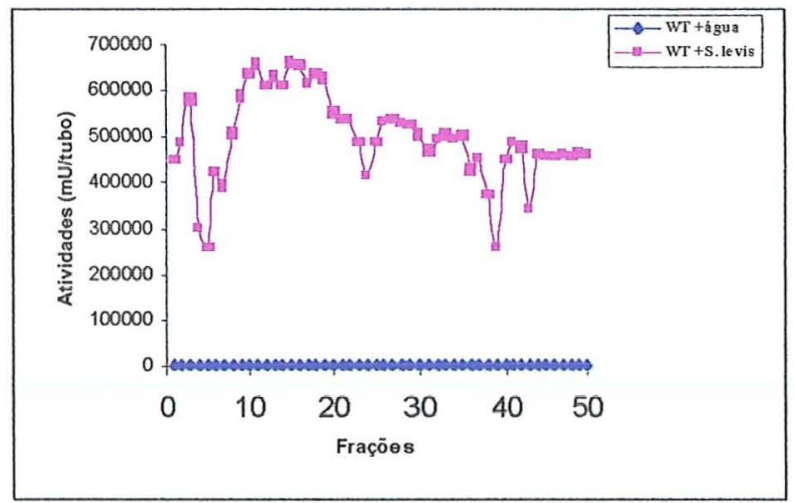

Figura 15 - Perfil de inibição sobre homogeneizado de S. levis obtido com a cromatografia da planta não transformada.

Apesar disto, os ensaios com as plantas transgênicas fora feitos com o mesmo tempo de fervura uma vez que ainda havia a possibilidade de observarmos alguma inibição na região da fração 20 (ver Figura 13) e uma inibição ainda maior entre as frações 1 e 10, resultante da ação conjunta da Chagasina e dos inibidores endógenos.

No entanto, os resultados dos ensaios com as frações das plantas transgênicas mostraram perfis de inibição semelhantes àqueles ocorridos na planta não transformada, sugerindo que a Chagasina expressa, por alguma razão, não foi capaz de inibir a atividade de $S$. levis . A Figura 16 mostra o resultado apenas de uma das plantas analisadas em comparação com a planta não transformada. 


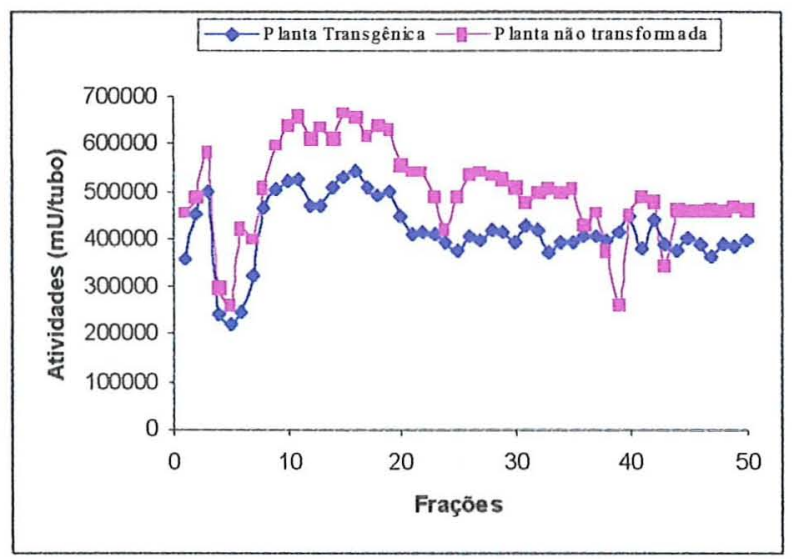

Figura 16 - Perfil de inibição sobre homogeneizado de S. levis obtido com a cromatografia de uma das plantas transgênicas.

Uma vez que a presença da proteína foi confirmada no ensaio de imunodetecção, uma provável explicação para a não ocorrência de inibição pela Chagasina seria sua baixa expressão nas plantas. Isto poderia ser decorrente do uso diferenciado de códons entre cana-de-açúcar e T. cruzi. A tabela 3 apresenta a seqüência de aminoácidos da Chagasina com seus respectivos códons acompanhados dos valores percentuais de uso dos mesmos nas duas espécies. Pode-se verificar que em alguns casos, há diferenças percentuais significativas no uso de um mesmo códon. Por exemplo, o acg que codifica para triptofano $n^{\circ} 14$ é o mais utilizado em $T$. cruzi $(39 \%)$, enquanto que em cana ele é o códon menos utilizado (20\%). Outros exemplos são a Lisina 3, a Treonina 5 entre outras.

Com base nesta tabela apenas, não é possivel afirmar se as diferenças observadas são suficientes para explicar que a baixa expressão da Chagasina é decorrente do uso diferenciado de códons entre as duas espécies. 
Tabela 3. Uso de códons em Tripanosoma cruzi e Saccharum officinarum.

\begin{tabular}{|l|c|c|c|c|c|c|c|c|c|c|c|c|c|}
\hline $\begin{array}{c}\text { Seqüência da } \\
\text { Chagasina }\end{array}$ & $\begin{array}{c}\mathrm{M} \\
\text { atg }\end{array}$ & $\begin{array}{c}\mathrm{S} \\
\text { tcc }\end{array}$ & $\begin{array}{c}\mathrm{H} \\
\mathrm{cac}\end{array}$ & $\begin{array}{c}\mathrm{K} \\
\text { aag }\end{array}$ & $\begin{array}{c}\mathrm{V} \\
\text { gtg }\end{array}$ & $\begin{array}{c}\mathrm{T} \\
\text { acg }\end{array}$ & $\begin{array}{c}\mathrm{K} \\
\text { aaa }\end{array}$ & $\begin{array}{c}\mathrm{A} \\
\text { gcc }\end{array}$ & $\begin{array}{c}\mathrm{H} \\
\text { cat }\end{array}$ & $\begin{array}{c}\mathrm{N} \\
\text { aac }\end{array}$ & $\begin{array}{c}\mathrm{G} \\
\text { ggc }\end{array}$ & $\begin{array}{c}\mathrm{A} \\
\text { gcc }\end{array}$ \\
\hline T. cruzi (\%) & 100 & 19 & 61 & 71 & 50 & 39 & 29 & 27 & 39 & 57 & 38 & 27 \\
\hline S. officinarum (\%) & 100 & 18 & 46 & 55 & 32 & 20 & 45 & 26 & 54 & 50 & 30 & 26 \\
\hline
\end{tabular}

\begin{tabular}{|l|c|c|c|c|c|c|c|c|c|c|c|c|}
\hline & 12 & 13 & 14 & 15 & 16 & 17 & 18 & 19 & 20 & 21 & 22 & 23 \\
\hline & $\begin{array}{c}\mathrm{T} \\
\mathrm{aca}\end{array}$ & $\begin{array}{c}\mathrm{L} \\
\mathrm{ttg}\end{array}$ & $\begin{array}{c}\mathrm{T} \\
\mathrm{acg}\end{array}$ & $\begin{array}{c}\mathrm{V} \\
\text { gtg }\end{array}$ & $\begin{array}{c}\mathrm{A} \\
\text { gcc }\end{array}$ & $\begin{array}{c}\mathrm{V} \\
\text { gtc }\end{array}$ & $\begin{array}{c}G \\
\text { Ggc }\end{array}$ & $\begin{array}{c}\mathrm{E} \\
\text { gag }\end{array}$ & $\begin{array}{c}\mathrm{L} \\
\text { ctc }\end{array}$ & $\begin{array}{c}\text { V } \\
\text { gtg }\end{array}$ & $\begin{array}{c}\text { E } \\
\text { gag }\end{array}$ & $\begin{array}{c}\text { att } \\
\text { att }\end{array}$ \\
\hline T. cruzi (\%) & 22 & 17 & 39 & 50 & 27 & 18 & 38 & 66 & 17 & 50 & 66 & 50 \\
\hline S. officinarum (\%) & 29 & 20 & 20 & 32 & 26 & 25 & 30 & 52 & 19 & 32 & 52 & 36 \\
\hline
\end{tabular}

\begin{tabular}{|l|c|c|c|c|c|c|c|c|c|c|c|c|}
\hline & 24 & 25 & 26 & 27 & 28 & 29 & 30 & 31 & 32 & 33 & 34 & 35 \\
\hline & $\begin{array}{c}\text { Q } \\
\text { cag }\end{array}$ & $\begin{array}{c}\mathrm{L} \\
\mathrm{ctt}\end{array}$ & $\begin{array}{c}\mathrm{P} \\
\mathrm{ccc}\end{array}$ & $\begin{array}{c}\mathrm{S} \\
\text { agc }\end{array}$ & $\begin{array}{c}\text { N } \\
\text { aat }\end{array}$ & $\begin{array}{c}\mathrm{P} \\
\text { ccc }\end{array}$ & $\begin{array}{c}\mathrm{T} \\
\text { acc }\end{array}$ & $\begin{array}{c}\text { T } \\
\text { acc }\end{array}$ & $\begin{array}{c}\text { G } \\
\text { ggg }\end{array}$ & $\begin{array}{c}\text { F } \\
\text { Ttc }\end{array}$ & $\begin{array}{c}\text { A } \\
\text { gcg }\end{array}$ & $\begin{array}{c}\text { W } \\
\text { tgg }\end{array}$ \\
\hline T. cruzi $\%$ ) & 69 & 23 & 25 & 21 & 43 & 25 & 22 & 22 & 20 & 38 & 33 & 100 \\
\hline S. officinarum (\%) & 47 & 18 & 22 & 19 & 50 & 22 & 27 & 27 & 21 & 53 & 21 & 100 \\
\hline
\end{tabular}

\begin{tabular}{|l|c|c|c|c|c|c|c|c|c|c|c|c|}
\multicolumn{1}{c}{} & 36 & 37 & 38 & 39 & 40 & 41 & 42 & 43 & 44 & 45 & 46 & 47 \\
\hline & $\begin{array}{c}\mathrm{Y} \\
\text { tat }\end{array}$ & $\begin{array}{c}\mathrm{F} \\
\mathrm{ttt}\end{array}$ & $\begin{array}{c}\mathrm{E} \\
\text { gaa }\end{array}$ & $\begin{array}{c}\mathrm{G} \\
\text { ggt }\end{array}$ & $\begin{array}{c}\mathrm{G} \\
\text { ggt }\end{array}$ & $\begin{array}{c}\mathrm{T} \\
\mathrm{Acc}\end{array}$ & $\begin{array}{c}\mathrm{K} \\
\text { aaa }\end{array}$ & $\begin{array}{c}\mathrm{E} \\
\text { gaa }\end{array}$ & $\begin{array}{c}\mathrm{S} \\
\text { agt }\end{array}$ & $\begin{array}{c}\mathrm{P} \\
\text { ccc }\end{array}$ & $\begin{array}{c}\mathrm{N} \\
\text { aat }\end{array}$ & $\begin{array}{c}\mathrm{E} \\
\text { gaa }\end{array}$ \\
\hline T. cruzi $\%)$ & 29 & 62 & 34 & 26 & 26 & 22 & 29 & 34 & 15 & 25 & 43 & 34 \\
\hline S. officinarum (\%) & 51 & 47 & 48 & 21 & 21 & 27 & 45 & 48 & 13 & 22 & 50 & 48 \\
\hline
\end{tabular}

\begin{tabular}{|l|c|c|c|c|c|c|c|c|c|c|c|c|}
\hline \multicolumn{1}{|c}{} & 48 & 49 & 50 & 51 & 52 & 53 & 54 & 55 & 56 & 57 & 58 & 59 \\
\hline & $\begin{array}{c}S \\
\text { tcc }\end{array}$ & $\begin{array}{c}\mathrm{M} \\
\text { atg }\end{array}$ & $\begin{array}{c}\mathrm{F} \\
\text { ttc }\end{array}$ & $\begin{array}{c}\mathrm{T} \\
\text { acc }\end{array}$ & $\begin{array}{c}\mathrm{V} \\
\text { gtc }\end{array}$ & $\begin{array}{c}\mathrm{E} \\
\text { gag }\end{array}$ & $\begin{array}{c}\mathrm{N} \\
\text { aat }\end{array}$ & $\begin{array}{c}\mathrm{K} \\
\text { aag }\end{array}$ & $\begin{array}{c}\mathrm{Y} \\
\text { tac }\end{array}$ & $\begin{array}{c}\mathrm{F} \\
\text { tt }\end{array}$ & $\begin{array}{c}\mathrm{P} \\
\text { cct }\end{array}$ & $\begin{array}{c}\mathrm{P} \\
\text { ccg }\end{array}$ \\
\hline T. cruzi $\%$ ) & 19 & 100 & 38 & 22 & 18 & 66 & 43 & 71 & 71 & 62 & 17 & 33 \\
\hline S. officinarum (\%) & 18 & 100 & 47 & 27 & 25 & 52 & 50 & 55 & 49 & 47 & 25 & 25 \\
\hline
\end{tabular}

\begin{tabular}{|c|c|c|c|c|c|c|c|c|c|c|c|c|}
\hline & 50 & 61 & 62 & 63 & 64 & 65 & 66 & 67 & 68 & 69 & 70 & 71 \\
\hline & $\begin{array}{c}\mathrm{D} \\
\text { gac }\end{array}$ & $\begin{array}{c}\mathrm{S} \\
\text { agt }\end{array}$ & $\begin{array}{c}\mathrm{K} \\
\text { aaa }\end{array}$ & $\begin{array}{c}\mathrm{L} \\
\mathrm{cta}\end{array}$ & $\underset{t t g}{L}$ & $\begin{array}{c}G \\
\text { ggt }\end{array}$ & $\begin{array}{c}\mathrm{A} \\
\mathrm{gct}\end{array}$ & $\begin{array}{c}\mathrm{G} \\
\mathrm{ggc}\end{array}$ & $\begin{array}{c}\mathrm{G} \\
\mathrm{ggg}\end{array}$ & $\begin{array}{c}T \\
\text { acg }\end{array}$ & $\begin{array}{c}E \\
\text { gag }\end{array}$ & $\begin{array}{c}\mathrm{H} \\
\mathrm{cac}\end{array}$ \\
\hline T. cruzi $(\%)$ & 56 & 15 & 29 & 4 & 17 & 26 & 19 & 38 & 20 & 39 & 66 & 61 \\
\hline S. officinarum (\%) & 45 & 13 & 45 & 10 & 20 & 21 & 27 & 29 & 21 & 20 & 52 & 46 \\
\hline
\end{tabular}

\begin{tabular}{|l|c|c|c|c|c|c|c|c|c|c|c|c|}
\multicolumn{1}{c|}{} & 72 & 73 & 74 & 75 & 76 & 77 & 78 & 79 & 80 & 81 & 82 & 83 \\
& $\begin{array}{c}\mathrm{F} \\
\mathrm{ttt}\end{array}$ & $\begin{array}{c}\mathrm{H} \\
\text { cat }\end{array}$ & $\begin{array}{c}\mathrm{V} \\
\text { gtg }\end{array}$ & $\begin{array}{c}\mathrm{T} \\
\text { aca }\end{array}$ & $\begin{array}{c}\mathrm{V} \\
\text { gtg }\end{array}$ & $\begin{array}{c}\mathrm{K} \\
\text { aag }\end{array}$ & $\begin{array}{c}\mathrm{A} \\
\text { gcg }\end{array}$ & $\begin{array}{c}\mathrm{A} \\
\text { gcc }\end{array}$ & $\begin{array}{c}\text { G } \\
\text { ggt }\end{array}$ & $\begin{array}{c}\mathrm{T} \\
\text { acg }\end{array}$ & $\begin{array}{c}\mathrm{H} \\
\text { cac }\end{array}$ & $\begin{array}{c}\mathrm{A} \\
\text { gca }\end{array}$ \\
\hline T. cruzi $\%)$ & 62 & 39 & 50 & 22 & 50 & 71 & 33 & 27 & 26 & 39 & 61 & 20 \\
\hline S. officinarum (\%) & 47 & 54 & 32 & 29 & 32 & 55 & 21 & 26 & 21 & 20 & 46 & 26 \\
\hline
\end{tabular}


$\begin{array}{llllllllllll}84 & 85 & 86 & 87 & 88 & 89 & 90 & 91 & 92 & 93 & 94 & 95\end{array}$

\begin{tabular}{|l|c|c|c|c|c|c|c|c|c|c|c|c|}
\hline & $\begin{array}{c}\mathrm{V} \\
\text { gta }\end{array}$ & $\begin{array}{c}\mathrm{N} \\
\text { aat }\end{array}$ & $\begin{array}{c}\mathrm{L} \\
\text { ctc }\end{array}$ & $\begin{array}{c}\mathrm{T} \\
\text { act }\end{array}$ & $\begin{array}{c}\mathrm{Y} \\
\text { tac }\end{array}$ & $\begin{array}{c}\mathrm{M} \\
\text { atg }\end{array}$ & $\begin{array}{c}\mathrm{R} \\
\mathrm{cgc}\end{array}$ & $\begin{array}{c}\mathrm{P} \\
\text { ccg }\end{array}$ & $\begin{array}{c}\text { W } \\
\text { tgg }\end{array}$ & $\begin{array}{c}\mathrm{T} \\
\text { aca }\end{array}$ & $\begin{array}{c}\mathrm{G} \\
\text { gga }\end{array}$ & $\begin{array}{c}\mathrm{P} \\
\text { ccc }\end{array}$ \\
\hline T. cruzi $(\%)$ & 8 & 43 & 17 & 16 & 71 & 100 & 30 & 33 & 100 & 22 & 16 & 25 \\
\hline S. officinarum (\%) & 16 & 50 & 19 & 24 & 48 & 100 & 18 & 25 & 100 & 29 & 29 & 22 \\
\hline
\end{tabular}

\begin{tabular}{|l|c|c|c|c|c|c|c|c|c|c|c|c|c|}
\multicolumn{1}{c}{96} & 97 & 98 & 99 & 100 & 101 & 102 & 103 & 104 & 105 & 106 & 107 \\
\hline & $\begin{array}{c}\mathrm{S} \\
\mathrm{tcg}\end{array}$ & $\begin{array}{c}\mathrm{H} \\
\mathrm{cac}\end{array}$ & $\begin{array}{c}\mathrm{D} \\
\text { gac }\end{array}$ & $\begin{array}{c}\mathrm{S} \\
\text { tcc }\end{array}$ & $\begin{array}{c}\mathrm{E} \\
\text { gag }\end{array}$ & $\begin{array}{c}\mathrm{R} \\
\mathrm{cgt}\end{array}$ & $\begin{array}{c}\mathrm{F} \\
\text { ttc }\end{array}$ & $\begin{array}{c}\mathrm{T} \\
\text { act }\end{array}$ & $\begin{array}{c}\mathrm{V} \\
\text { gta }\end{array}$ & $\begin{array}{c}\mathrm{Y} \\
\text { tat }\end{array}$ & $\begin{array}{c}\mathrm{L} \\
\text { ctc }\end{array}$ & $\begin{array}{c}\mathrm{K} \\
\text { aag }\end{array}$ \\
\hline T. cruzi $\%$ ) & 18 & 61 & 56 & 19 & 66 & 23 & 38 & 16 & 8 & 29 & 17 & 71 \\
\hline S. officinarum (\%) & 14 & 46 & 45 & 18 & 52 & 12 & 53 & 24 & 16 & 52 & 19 & 55 \\
\hline
\end{tabular}

\begin{tabular}{|l|c|c|c|c|c|c|c|c|c|c|c|c|}
\hline & 108 & 109 & A & N & STOP \\
gca & aac & tga & & & & & & & & & \\
\hline T. cruzi $(\%)$ & 20 & 57 & 55 & & & & & & & & & \\
\hline S. officinarum (\%) & 26 & 50 & 58 & & & & & & & & & \\
\hline
\end{tabular}




\section{CONCLUSÕES}

Os resultados obtidos nos permitem concluir que :

1 - A principal atividade proteinásica presente em larvas de $S$. levis é decorrente da ação de cisteino proteinases semelhantes às catepsinas $L$.

2 - Chagasina é um potente inibidor de cisteíno proteinases $\left(K_{D}=160 \mathrm{pM}\right)$ de S. levis.

3 - A presença da Chagasina nas plantas transgênicas de cana-de-açúcar não foi suficiente para anular a atividade de cisteino proteinases de $S$. levis, provavelmente em função do baixo nivel de expressão. 


\section{REFERÊNCIAS BIBLIOGRÁFICAS}

ABE, K.; EMORI, Y.; KONDO, H.; SUZUKI, K.; ARAI, S. Molecular cloning of a cysteine proteinase inhibitor of rice (oryzacystatin). The Journal of Biological Chemistry, v.262, n.35, p.16793-16797, 1987.

ABE, M.; ABE, K.; KURODA, M.; ARAI, S. Corn kernel cysteine proteinase inhibitor as a novel cystatin superfamily member of a plant origin. European Journal of Biochemistry, v.209, p.933-937, 1992

ALVES, L.C.; ALMEIDA, P.C.; FRANZONI, L.; JULIANO, L.; JULIANO, M.A. Synthesis of $\mathrm{N}$-alpha-protected aminoacyl 7-amino-4-methyl-coumarin amide by phosphorous oxychloride and preparation of specific fluorogenic substrates for papain. Peptide Research, v.9, n.2, p.92-96, 1996.

BANBULLA, A.; MAK, P.; SMOLUCH, M. et al. Arginine-specific cysteine proteinase from Porphyromonas gingivalis as a convenient tool in protein chemistry. Biological Chemistry, v.382, n.9, p.1399-1404, 2001.

BARRET, A. J.; KEMBHAVI, A. A.; BROWN, M. A.; KIRSCHKE, H.; KNIGHT, C. G.; TAMTI, M.; HANADA, K. L-trans-Epoxysuccinyl-leucylamido (4-guanidino) butane (E-64) and its analogues as inhibitors of cysteine proteinases including cathepsins B, H and L. Biochemistry Journal, v.201, p.189-198, 1982. 
BARRETT, A.J.; RAWLINGS, N.D. Evolutionary lines of cysteine peptidases. Biological Chemistry, v.382, n.5, p.727-733, 2001.

BARTON, K.; WHITELY, H.; YANG, N.S. Bacillus thuringiensis $\delta$-endotoxin in transgenic Nicotiana tabacum provides resistance to lepidopteran insects. Plant Physiology, v.85, p.1103-1109, 1987.

BENCHEKROUN, A.; MICHAUD, D.; NGUYEN-QUOC, B. et al. Synthesis of active oryzacystatin I in transgenic potato plants. Plant Cell Reports, v.14 p.585-588, 1995.

BIAN, S.; SHAW, B.D.; HAN, Y.; CHRISTELLER, J. T. Midgut proteinase activities in larvae of Anoplophora glabripennis (Coleoptera: Cerambycidae) and their interactions with proteinase inhibitors. Archives of Insect Biochemistry and Physiology, v.31, p.23-37, 1996.

BLANCO-LABRA, A.; MARTINEZ-GALLARDO, N. A.; SANDOVAL-CARDOSO, L.; DELANO-FRIER, J. Purification and Characterization of a Digestive Cathepsin D Proteinase Isolated from Tribolium castaneum Larvae (Herbst). Insect Biochemistry and Molecular Biology, v.26, n.1, p.95-100, 1996.

BONADÉ-BOTTINO, M.; LERIN, J.; ZACCOMER, B.; JOUANIN, L. Physiological adaptation explains the insensitivity of Baris coerulescens to transgenic oilseed rape expressing oryzacystatin I. Insect Biochemistry and Molecular Biology, v.29, n.2, p.131-138, 1999.

BRADFORD, M.M. A rapid and sensitive method for the quantification of microgram quantities of protein utilizing the principle of protein-dye binding. Annals of Biochemistry, v.72, p.248-254, 1976. 
BROADWAY, R.M. Are insects resistants to plant proteinase inhibitors? Journal of Insect Physiology, v.41, n.2, p.107-116, 1995.

CHEN, M.; JOHNSON, B.; WEN, L.; MUTHUKRIHNAN, S. et al. Rice cystatin: bacterial expression, purification, cysteine proteinase inhibitory activity and insect growyh suppressing activity of a truncated form of the protein. Protein Expression and Purification, v.3, p.41-49, .

CHRISTELLER, J.; LAING, W.; MARKWICK, N.; BURGESS, E. Midgut protease activities in 12 phytofagous lepidopteran larvae: dietary and protease inhibitor interactions. Insect Biochemistry and Molecular Biology, v.22, p.735-746, 1992.

CHRISTENSEN A. H.; QUAIL P.H. Ubiquitin promoter-based vectors for highlevel expression of selectable and/or screenable marker genes in monocotyledonous plants. Transgenic Research, v.5, n.3, p.213-218, 1996.

CRISTOFOLETTI, P.T.; TERRA, W.R. The role of amino acid residues in the active site of a midgut microvillar aminopeptidase from the beetle Tenebrio molitor. Biochemica and Biophysica Acta, v.1479, n.12, p.185-195, 2000.

CZAPLEWSKI, C.; GRZONKA, Z.; JASKÓLSKI, M. et al. Binding modes of a new epoxysuccinyl-peptide inhibitor of cysteine proteases. Where and how do cysteine proteases express their selectivity? Biochemica and Biophysica Acta, v.43, p.290-305, 1999.

DEGASPARI, N.; BOTELHO, P.S.M.; ALMEIDA, L.C.; CASTILHO, H.J. Biologia de Sphenophorus levis Vaurie, 1978 (Col: Curculionidae), em dieta artificial e no campo. Pesquisa Agropecuária Brasileira, v.22, n.6, p.553-558, 1987. 
FALCO, M.C.; MENDES, B.M.J.; TULMANN NETO, A.; GLÓRIA, B. A Histological characterization of in vito regeneration of Saccharum sp. Revista Brasileira de Fisiologia Vegetal, v.8, n.2, p.93-97, 1996.

FINER, J.J.; MCMULLEN, M.D. Transformation of cotton (Gossypium hirsutum L.) via bombardment. Plant Cell Reports, v.8, p.586-589, 1990.

FISCHHOFF, D.A.; BOWDISH, K.S.; PERLACK, F.J. et al. Insect tolerant transgenic tomato plants. Bio/Technology, v.5, p.807-812, 1987.

FRUTOS, R.; RANG, C.; ROYER, M. Managing insect resistance to plants producing Bacillus thuringiensis toxins. Critical Reviews in Biotechnology, v.19, n.3, p.227-276, 1999.

GATEHOUSE, A.M.R.; DAVIDSON, G.M.; NEWELL, C.A. Transgenic potato plants with enhanced resistance to the tomato moth Lacanobia oleracea: growth room trials. Molecular Breeding, v.3, p.1-15, 1997.

GATEHOUSE, A.M.R.; GATEHOUSE, J.A. Identifying proteins with insecticidal activity: use of encoding genes to produce insect-resistant transgenic crops. Pesticide Science, v.52, p.165-175, 1998.

GATEHOUSE, A.M.R.; GATEHOUSE, J.A.; DOBIE, P. et al. Biochemical basis of insect resistance in Vigna unguiculata. Journal of the Science of Food and Agriculture, v.30, p.948-958, 1979.

GILLIKIN, J.W.; BEVILACQUA, S.; GRAHAM, J.S. Partial characterization of digestive-tract proteinases from western corn-rootworm larvae, diabroticavirgifera. Archives of Insect Biochemistry and Physiology, v.19, n.4, p.285-298, 1992. 
GIRARD, C.; BONADE-BOTTINO, M.; PHAM-DELEGUE, M. H.; JOUANIN, L. Two strains of cabbage weevil (Coleoptera: Curculionidae) exhibit differential susceptibility to a transgenic oilseed rape expressing oryzacystatin I. Journal of Insect Physiology, v.44, p.569-577, 1998.

GIRARD, C.; METAYER, M.L.; BONADE-BOTTINO, M. et al. High level of resistance to proteinase inhibitor may be conferred by proteolytic cleavage in beetle larvae. Insect Biochemistry and Molecular Biology, v.28, n.4, p.229-237, 1998.

GIRARD, C.; METAYER, M.L.; ZACCOMER, B. et al. Growth stimulation of beetle larvae on expressing a cysteine proteinase inhibitor. Journal of Insect Physiology, v.44, p.263-270, 1998.

GOULD, F.; ANDERSON, A.; JONES, A. et al. Initial frequence of alleles for resistance to Bacillus thuringiensis toxins in field population of Heliothis virescens. Proceedings of the National Academy of Sciences of the USA, v.94, p.3519-3523, 1997.

GREEN, T.R.; RYAN, C.A. Wound-induced proteinase inhibitor in plant leaves; a possible defence mechanism against insects. Science, v.175, p.776-777, 1972.

GUTIERREZ-CAMPOS, R.; TORRES-ACOSTA, J.A.; SAUCEDO-ARIAS, L.J.; GOMEZ-LIM, M.A. The use of cysteine proteinase inhibitors to engineer resistance against potyviruses in transgenic tobacco plants. Nature Biotechnology, v.17, p.1223-1226, 1999.

HILDER, V.A.; BOULTER, D. Genetic engineering of crop plants for insect resistance - a critical review. Crop Protection, v.18, p.177-191, 1999. 
HILDER, V.A.; GATEHOUSE, A.M.R.; SHEERMAN, S.E. et al. A novel mechanism of insect resistance engineered into tobacco. Nature, v.330, p.160-163, 1987.

HOSOYAMA, H.; IRIE, K.; ABE, K.; ARAI, S. Oryzacystatin exogenously introduced into protoplasts and regeneration of transgenic rice. Bioscience Biotechnology and Biochemistry, v.58, p.1500-1505, 1994.

JOHNSON, K.A.; NARVAEZ, A.N.; RYAN, C.A. Expression of proteinase inhibitors I and II in transgenic tobacco plants: effects on natural defense against Manduca Sexta larvae. Proceedings of the National Academy of Sciences of the USA, v.86, p.9871-9875, 1989.

JOHNSTON, K.; LEE, M.; BROUGH, C.; HILDER, V.; GATEHOUSE, A.; GATEHOUSE, J. Protease activities in the larval midgut of Heliothis virescens: evidence for trypsin and chymotrypsin-like enzymes. Insect Biochemistry and Molecular Biology, v.25, p.375-383, 1995.

JONGSMA, M.A.; BOLTER, C. The adaptation of insects to plant protease inhibitors. Journal of Insect Physiology, v.43, n.10, p.885-895, 1997.

JOUANIN, L.; BONADÉ-BOTTINO, M.; GIRARD, C.; MORROT, G.; GIBAND, M. Transgenic plants for insect resistance. Plant Science, v.131, p.1-11, 1998.

KASSCHAU, K.; CARRINGTON, J. Requirement for HC-pro processing during genome amplification of tobacco etch potyvirus. Virology, v.209, p.268-273, 1995. 
KNIGHT, C.G.; BARRET, A.J. Interaction of human cathepsin D with the inhibitor pepstatin. Biochemical Journal, v.155, p.117-125, 1976.

KOIWA, H.; SHADE, R.E.; ZHU-SALZMAN, K. et al. A plant defensive cystatin (soyacystatin) targets cathepsin L-like digestive cysteine proteinases (DVCALs) in the larval midgut of western corn rootworm (Diabrotica virgifera virgifera). FEBS Letters, v.471, p.67-70, 2000.

LECARDONNEL, A.; CHAUVIN, L.; JOUANIN, L.; BEAUJEAN, A.; PRÉVOST, G.; SANGWAN-NORREEL, B. Effects of rice cystatin 1 expression in transgenic potato on colorado potato beetle larvae. Plant Science, v.140, p.87-98, 1999.

LEMOS, F.J.A.; TERRA, W.R. Properties and intracellular distribution of a cathepsin $D$-like proteinase active at the acid region of Musca domestica midgut. Insect Biochemistry, v.21, n.5, p.457-465, 1991.

LEPLÉ, J.C.; BONADÉ-BOTTINO, M.; AUGUSTIN, S. Toxicity to Chrysomela tremulae (Col.: Chrysomelidae) of transgenic poplars expressing a cysteine proteinase inhibitor. Molecular Breeding, v.1, p.319-328, 1995.

LOMONOSSOFF, G.P. Pathogen-derivated resistance to plant viruses: Annual Review of Phytopatology, v.33, p.323-343, 1995

MAAGD, R.A.; BOSCH, D.; STIEKENS, W. Bacillus thuringiensis toxin-mediated insect resistance in plants. Trends in Plant Science, v.4, n.1, p.9-13, 1999.

MAITI, I.B.; MURPHY, J.F.; SHAW, J.G.; HUNT, A.G. Plants that express a potyvirus proteinase gene are resistant to virus infection. Proceedings of the National Academy of Sciences of the USA, v.90, p.6110-6114, 1993. 
MASOUD, S.A.; JOHNSON, L.B.; WHITE, F.F.; REECK, G.R. Expression of a cysteine proteinase inhibitor (oryzacystatin I) in transgenic tobacco plants. Plant Molecular Biology, v.21, p.655-663, 1993.

MAZUMDAR-LEIGHTON, S.; BROADWAY, R. M. Transcriptional induction of diverse midgut trypsins in larval Agrotis ipsilon and Helicoverpa zea feeding on the soybean trypsin Inhibitor. Insect Biochemistry and Molecular Biology, v.31, n.6-7, p.645-657, 2001.

MCMANUS, M.T.; WHITE, D.W.R.; MCGREGOR, P.G. Accumulation of a chymotrypsin inhibitor in transgenic tobacco can affect the growth of insect pests. Transgenic Research, v.3, p.50-58, 1994.

MICHAUD, D.; CANTIN, L.; BONADÉ-BOTTINO, M.; JOUANIN, L.; VRAIN, T.C. Identification of stable plant cystatin/nematode proteinase complexes using miloly denaturing gelatin/polyacrylamide gel electroforesis. Electroforesis, v.17, p.1-7, 1995.

MONTEIRO, A.C.S.; ABRAHAMSON, M.; LIMA, A.P.C.A. et al. Identification, characterization and localization of chagasin, a tight-binding cysteine protease inhibitor in Trypanosoma cruzi. Journal of Cell Science, v.114, n.21, p.3933-3942, 2001.

MURASHIGE, T.; SKOOG, F. A revised medium for rapid growth and bioassays with tobacco tissue cultures. Physiologia Plantarum, v.15, p.473-497, 1962.

MURDOCK L.L.; BROOKHART, G.; DUNN, P.E. et al. Cysteine digestive proteinases in coleoptera. Comparative Biochemistry and Physiology B, v.87, n.4, p.783-787, 1987. 
NOVILLO, C.; CASTAÑERA, P.; ORTEGO, F. Inhibition of digestive trypsin-like proteases from larvae of several lepidopteran species by the diagnostic cysteine protease inhibitor E-64. Insect Biochemistry and Molecular Biology, v.27, n.3, p.247-254, 1997.

OERKE, E-C. Estimated crop losses due to pathogens, animal pests and weeds. In: OERKE, E-C.; DEHNE, H-W.; SCHÖNBECK, F.; WEBER, A. Crop production and crop protection: estimated losses in major food and cash crops. Amsterdam: Elsevier Science, 1994. chap.3, p.72-735.

PANDA, N.; KHUSH, G.S. Host plant resistance to insects. Wallingford: CAB INTERNATIONAL; Manila: International Rice Research Institute, 1995. 431p.

PATANKAR, A. G.; GIRI, ASHOK P.; HARSULKAR, ABHAY M.; SAINANI, MOHINI N.; DESHPANDE, VASANTI V. et al. Complexity in specificities and expression of Helicoverpa armigera gut proteinases explains polyphagous nature of the insect pest. Insect Biochemistry and Molecular Biology, v.31, n.4-5, p.453-464, 2001.

PIETRANTONIO, P.V.; GILL, S.S. Bacillus thuringiensis endotoxins: action on the insect midgut. In: LEHANE, M.J.; BILLINGSLEY, P.F. Biology of the Insect Midgut. New York: Chapman and Hall, 1996. chap.13, p.345-372.

RAWLINGS N.D.; BARRETT, A.J. Families of cysteine peptidases. Methods in Enzymolology, v.244, p.461-486, 1994.

REDDEN, R.J.; DOBIE, P.; GATEHOUSE, A.M.R. The inheritance of seed resistance to Callosobruchus maculatus $F$, in cowpea (Vigna unguiculata I. Walp.). Analysis of parental, $F_{1}, F_{2}, F_{3}$ and backcross seed generations. Australian Journal of Agricultural Research,v.34, p.681-695, 1983. 
RYAN, C. A. Protease inhibitor in plants: genes for improving defenses against insect and pathogens. Annual Review of Phytopathology, v.28, p.425-449 1990.

SAMBROOK, J.; FRITSCH, E.F.; MANIATIS, T. Molecular Cloning: a laboratory manual. 2.ed. New York: Cold Spring Harbor Laboratory Press, 1989.

SANFORD, J.C.; JOHNSON, S.A. The concept of parasite-derivated resistance: deriving resistance genes from the parasites own genome. Journal of Theoretical Biology, v.115, p.395-405, 1985.

SCHULER, T.H.; POPPY, G.M.; KERRY, B.R.; DENHOLM, I. Insect-resistant transgenic plants. Trends in Biotechnology, v.16, n.4, p.168-175, 1998.

SHUMWAY, L.K.; YANG, V.V.; RYAN, C.A. Evidence for the presence of proteinase inhibitor I in vacuolar protein bodies of plant cells. Planta, v.129, p.161-165, 1976.

SILVA, C.; XAVIER-FILHO, J. Comparison between the levels of aspartic and cysteine proteinases of the larval midguts of Callosobruchus maculatus (L.) and Zabrotes subfasciatus (Boh.) (Coleoptera: Bruchidae). Comparative Biochemistry and Physiology B, v.99, p.529-533, 1991.

TAYLOR, P.W.J.; KO, H.; ADKINS, S.W.; RATHUS, C.; BIRCH, R.G. Establishment of embryogenic callus and high protoplast yelding suspension cultures of sugarcane (Sccharum spp. hybrids). Plant Cell, Tissue and Organ Culture, v.28, p.69-78, 1992. 
TERRA W.R.; CRISTOFOLETTI, P.T. Midgut proteinases in three divergent species of Coleoptera. Comparative Biochemistry and Physiology, v.113, n.4, p.725-730, 1996.

TERRA, W.R.; FEREIRA, C.; BACKER, J.E. Compartmentalization of digestion. In: LEHANE, M.J.; BILLINGSLEY, P.F. Biology of the insect midgut. New York: Chapman and Hall, 1996. chap.8, p.206-235.

TERRA, W.R.; FEREIRA, C.; JORDÃO, B.P.; DILLON, R.J. Digestive Enzymes. In: LEHANE, M.J.; BILLINGSLEY, P.F. Biology of the insect midgut. New York: Chapman and Hall, 1996. chap.6, p.153-194.

TERRA, W.R.; FERREIRA, C. Insect digestive enzymes: properties, compartmentalization and function. Comparative Biochemistry and Physiology, v.109, n.1, p.1-62, 1994.

TURK, B.; TURK, V.; TURK, D. Structural and functional aspects of papain-like cystein proteinases and their protein inhibitors. Biological Chemistry, v.378, p.141-150, 1997.

TWINING, S.S. Fluorescein isothiocyanate-labeled casein assay for proteolytic enzymes. Analytical Biochemistry, v.143, p.30-34, 1984.

UHLMANN, F.; WERNIC, D.; POUPART, M. A et al. Cleavage of cohesin by the $C D$ clan protease separin triggers anaphase in yeast. Cell, v.103, n.3, p.375$386,2000$. 
URWIN, P.E.; ATKINSON, H.J.; WALLER, D.A.; MCPHERSON, M.J. Engineered oryzacystatin 1 expressed in transgenic hairy roots confers resistance to Globodera pallida. The Plant Journal, v.8, n.1, p.121-131, 1995.

VAECK, M.; REYNAERTS, A.; HOFTE, H.; JANSENS, S. et al. Transgenic plants protected from insect attack. Nature, v.327, p.33-37 1987.

VAIN, P.; WORLAND, B.; CLARKE, M.C. et al. Expression of an engineered cysteine proteinase inhibitor (oryzacystatin-I $\triangle \mathrm{D} 86$ ) for nematode resistance in transgenic rice plants. Theoretical and Appllied Genetics, v.96, p.266-271, 1998.

VALAITIS, A.P.; SYLVIE. A.B.; KAREN, M.; CLANCY, C. Purification and characterization of the western spruce budworm larval midgut proteinases and comparison of gut activities of laboratory-reared and field-collected insects. Insect Biochemistry and Molecular Biology, v.29, n.5, p.405-415, 1999.

WALKER, A.J.; FORD, L.; MAJERUS, M.E.N. et al. Characterization of the midgut digestive proteinase activity of the two spot ladybird (Adalia bipunctata $\mathrm{L}$ ) and its sensitivity to proteinase inhibitors. Insect Biochemistry and Molecular Biology, v.28, n.3, p.173-180, 1998.

WILHITE, S.E.; ELDEN, T.C.; BRZIN, J.; SMIGOCKI, A.C. Inhibition of cysteine and aspartyl proteinases in the alfalfa weevil midgut with biochemical and plant-derived proteinase inhibitors. Insect Biochemistry and Molecular Biology, v.30, n.12, p.1181-1188, 2000. 
WILLADSEN, P.; BILLINGSLEY, P.F. Immune intervention against bloodfeeding insects. In: LEHANE, M.J.; BILLINGSLEY, P.F. Biology of the insect midgut. New York: Chapman and Hall, 1996. chap.12, p.323-344.

WOLFSON, J.; MURDOCK, L. Diversity in digestive proteinase activity among insects. Journal of Chemical Ecology, v.16, n.4, p.1089-1102, 1990.

XU, D.; XUE, Q.; MCELROY, D; MAWAL, Y.; HILDER, V.A. Constitutive expression of a cowpea trypsin inhibitor gene, $\mathrm{CpTi}$, in transgenic rice plants confers resistance to two major insect pests. Molecular Breeding, v.2, p.167173, 1996. 